\title{
Circular Digital Built Environment: An Emerging Framework
}

\author{
Sultan Çetin ${ }^{1, *(\mathbb{D})}$, Catherine De Wolf ${ }^{1,2}$ and Nancy Bocken ${ }^{3}$ (D) \\ 1 Faculty of Architecture and the Built Environment, Delft University of Technology, Julianalaan 134, \\ 2628 BL Delft, The Netherlands; cdewolf@ethz.ch \\ 2 Chair of Circular Engineering for Architecture, Department of Civil, Environmental and Geomatic \\ Engineering, Swiss Federal Institute of Technology in Zürich (ETH Zürich), Stefano-Franscini-Platz 5, \\ 8093 Zurich, Switzerland \\ 3 Maastricht Sustainability Institute, School of Business and Economics, Maastricht University, \\ Tapijn 11 Building D, P.O. Box 616, 6200 MD Maastricht, The Netherlands; \\ Nancy.Bocken@maastrichtuniversity.nl \\ * Correspondence: S.Cetin-Ozturk@tudelft.nl; Tel.: +31-15-278-1517
}

\section{check for}

updates

Citation: Çetin, S.; De Wolf, C.; Bocken, N. Circular Digital Built Environment: An Emerging Framework. Sustainability 2021, 13, 6348. https://doi.org/10.3390/ su13116348

\section{Academic Editors:}

Gianmarco Bressanelli,

Federico Adrodegari, Daniela

Cristina Antelmi Pigosso and Vinit Prida

Received: 26 April 2021

Accepted: 31 May 2021

Published: 3 June 2021

Publisher's Note: MDPI stays neutral with regard to jurisdictional claims in published maps and institutional affiliations.

Copyright: (c) 2021 by the authors. Licensee MDPI, Basel, Switzerland. This article is an open access article distributed under the terms and conditions of the Creative Commons Attribution (CC BY) license (https:// creativecommons.org/licenses/by/ $4.0 /)$.

\begin{abstract}
Digital technologies are considered to be an essential enabler of the circular economy in various industries. However, to date, very few studies have investigated which digital technologies could enable the circular economy in the built environment. This study specifically focuses on the built environment as one of the largest, most energy- and material-intensive industries globally, and investigates the following question: which digital technologies potentially enable a circular economy in the built environment, and in what ways? The research uses an iterative stepwise method: (1) framework development based on regenerating, narrowing, slowing and closing resource loop principles; (2) expert workshops to understand the usage of digital technologies in a circular built environment; (3) a literature and practice review to further populate the emerging framework with relevant digital technologies; and (4) the final mapping of digital technologies onto the framework. This study develops a novel Circular Digital Built Environment framework. It identifies and maps ten enabling digital technologies to facilitate a circular economy in the built environment. These include: (1) additive/robotic manufacturing, (2) artificial intelligence, (3) big data and analytics, (4) blockchain technology, (5) building information modelling, (6) digital platforms/marketplaces, (7) digital twins, (8) the geographical information system, (9) material passports/databanks, and (10) the internet of things. The framework provides a fruitful starting point for the novel research avenue at the intersection of circular economy, digital technology and the built environment, and gives practitioners inspiration for sustainable innovation in the sector.
\end{abstract}

Keywords: circular economy; digital technology; digitalisation; built environment; construction; buildings; framework; circular strategies; circular business models; circular design; sustainability

\section{Introduction}

By 2050, roughly two-thirds of the world's population will be living in cities [1]. By 2030, three billion people will need new housing [2]. However, today's construction sector is the most resource-intensive sector in industrialized countries [3], using 50\% of all materials consumed in Europe [4], creating 36\% of the total waste in the European Union (EU) [5], and emitting 39\% of our global energy-related greenhouse gas emissions [6] due to its linear model: we extract, produce, use, and dispose of building materials and resources. The challenge for all of the stakeholders of the built environment $(\mathrm{BE})$ is to respond to global housing needs while reducing environmental impacts. However, this is no easy task. Considering that the construction industry forms about $9 \%$ of the European gross domestic product [7], it is essential to drive the paradigm shift from a linear to a circular BE. Indeed, in order to address the emissions, resource depletion and waste caused by this industry, a transition to a circular model is urgently needed. 
The Circular Economy (CE) concept is not new, and some would refer to it as old wine in new bottles [8]. Indeed, the work by Boulding (1966) on Spaceship Earth [9] and Commoner's Four Laws of Ecology [10] and later work on cradle-to-cradle [11], biomimicry [12], and the slowing and closing loops [13] form some of the foundations of what is now known as the CE [14]. Organisations such as the Ellen MacArthur Foundation (EMF) helped popularise the concept, and it is now embedded in business goals as well as various (inter)national policies, such as in the Circular Economy Promotion Law in China and the Circular Economy Package in the EU [14].

The CE concept has been discussed and interpreted differently by many scholars, practitioners, and policy makers [15]. Building on [16-19], we consider the CE to be a system that supports sustainable development to secure the resources to sustain our current and future generations by minimizing the resource inputs and waste, emissions, and energy leakage of products over time, which may be achieved through four distinct resource strategies:

1. Narrowing the loop: using fewer resources through efficiencies in the production and design process.

2. Slowing the loop: using and consuming less, through long product life, product life extension and avoiding unnecessary consumption.

3. Closing the loop: reusing materials, or post-consumer recycling.

4. Regenerating the loop: focusing on leaving the environment (and society) in a better state than before, e.g., by improving biodiversity.

Promoted by the EMF, the CE principles applied to the BE sector have been illustrated in different industry reports [20,21]. Iacovidou and Purnell [22] demonstrated that mining the physical infrastructure through the reuse of building components leads not only to the conservation of resources but also to the development of new business models and the creation of environmental, technical, and social value. Formed by a multistakeholder consortium, the Buildings as Material Bank (BAMB) project [23] has been one of the pioneers in developing and testing circular strategies and tools to recover value from buildings. Other examples of such pioneers include Rotor [24], Cycle Up [25], and Baubüro in situ [26]. However, the lack of cross-sector communication and coordination tools needs to be addressed in order to enable the broad implementation of a feasible circular design strategy in current construction practice [27]. Digitalisation could offer some of the tools needed.

Digital transformation, next to the CE transition, has been proclaimed as one of the priority areas of the EU in a recent announcement of 'Europe's Digital Decade' [28]. This vision aims not only to empower people and businesses but also to support the transition to a climate-neutral, circular and resilient economy [28]. Likewise, in the 2020 EU CE Action Plan [29], innovation and digitalisation were seen as drivers for tracking, tracing and mapping resources and dematerialising the economy for lower dependency on natural resources. Thus, we can see a clear link between digitalisation and CE in the policy environment within the European context.

Furthermore, digital technologies (DTs), which some scholars refer to as Industry 4.0 technologies, are thought to be essential for the transition to a $\mathrm{CE}$ in various industries [30-35]. The research concentrating on the intersection between the CE and DTs is still immature, as the number of publications started to grow from the mid-2010s onwards [32,34] (See also Figure 1). Several researchers sought to identify suitable DTs for the support of the transition to a CE or introduced integrative frameworks [31,32,34], while others focused on their role in circular business models, particularly in product-service systems [30,33]. Within the context of the CE, the DTs which are frequently referred to are additive manufacturing (AM), cyber-physical systems, the internet of things (IoT), and big data and analytics (BDA) $[30,31,33,34]$. These DTs are found to be supportive of varying circular strategies such as enhancing product design [30], sustainable operations management [31], resource efficiency [34], the optimisation of resource flows [33], and the tracking and tracing of post-use products [31]. 


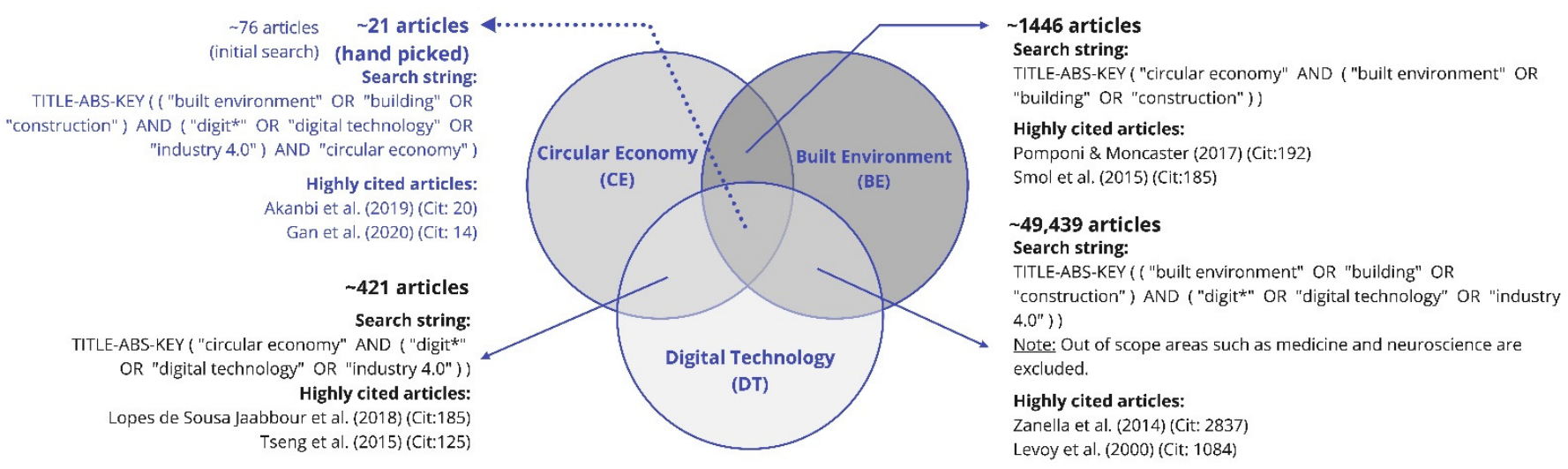

Figure 1. Literature search results on the intersections among Circular Economy (CE), Built Environment (BE) and Digital Technology (DT). The results were extracted from the Scopus database (February 2021). See Table S1 in the Supplementary Materials for 21 articles on the intersection between CE, BE and DTs.

Compared to other sectors, the digital transformation has been slow in the BE industry, but there have been considerable developments in the last few decades [36]. The focus has been mainly on the relatively new uptake of Building Information Modelling (BIM) and digital twins [37], sometimes exploring the link to blockchain technology [38] and the Internet of Things (IoT) $[39,40]$ to manage buildings. Pilot projects have also demonstrated the feasibility of digital fabrication [41]. The Geographical Information System (GIS) is used at an urban scale in the decision-making process [42]. The construction sector's value chain is known to be fragmented $[43,44]$, which is why digital platforms are being developed more and more $[43,45]$. Research is also being conducted regarding the use of Artificial Intelligence (AI) [46] in different fields in the sector.

From a CE perspective, some of these technologies have received great attention from both practice and academia. Several material passport concepts have emerged, e.g., Madaster [47]; BIM platforms and add-ins have been developed to estimate the recoverability of materials in various design alternatives [48-50], and to facilitate efficient data flows and supply chain collaboration [43,51]; recycled materials have been tested in concrete mixes with AM [52]; IoT systems have been designed to track materials for reuse across the life cycle stages [53-55].

Despite the broadly acknowledged opportunities that these DTs offer, no articles have been identified by the authors that comprehensively investigate which DTs could potentially support a CE throughout the life cycle stages of buildings. As shown in Figure 1, a literature search on the Scopus database yielded 21 articles on the intersection between $\mathrm{BE}$, CE and DTs (after eliminating the papers that were not relevant). These articles, similarly to the above mentioned examples, focus on the development or implementation of a particular technology for a certain circular strategy in a specific life cycle stage. Therefore, there is a lack of a thorough overview of the DTs, which could enable the circular transition of the BE. In order to contribute to the building of knowledge on this matter, this article addresses the following research question: which digital technologies potentially enable a Circular Economy in the built environment, and in what ways? The study adopts an iterative stepwise approach, consisting of four steps: framework development; expert workshops; the literature and practice review; and the mapping of enabling DTs.

The remainder of this article is structured as follows. Section 2 displays the research design and methods. Section 3 introduces the Circular Digital Built environment framework (CDB framework) that was developed based on life cycle stages in buildings and the four core CE principles of regenerating, narrowing, slowing and closing resource loops. Furthermore, Section 4 presents the empirical findings from the expert workshops, while Section 5 focuses on the literature and practice to explore the enabling functions of the identified DTs. Based on the findings from the previous sections, Section 6 maps ten enabling DTs onto the CDB framework and demonstrates the interdependencies of these 
technologies. Finally, Section 7 elaborates on the research contributions, implications for practice, and limitations.

\section{Research Design and Methods}

Given the emerging characteristics of DTs in the CE, an exploratory qualitative research approach was chosen based on an iterative stepwise method. The four overarching research steps presented in Figure 2 are: (1) the development of a framework for mapping enabling DTs; (2) the identification and initial mapping of DTs through expert workshops; (3) the literature and practice review; and (4) the final mapping of the identified DTs onto the framework. In a sense, our work can be considered to be an integrative review of three research domains $(\mathrm{CE}, \mathrm{BE}$, and $\mathrm{DTs})$ that formulates an initial conceptualisation of an emerging research field [56].

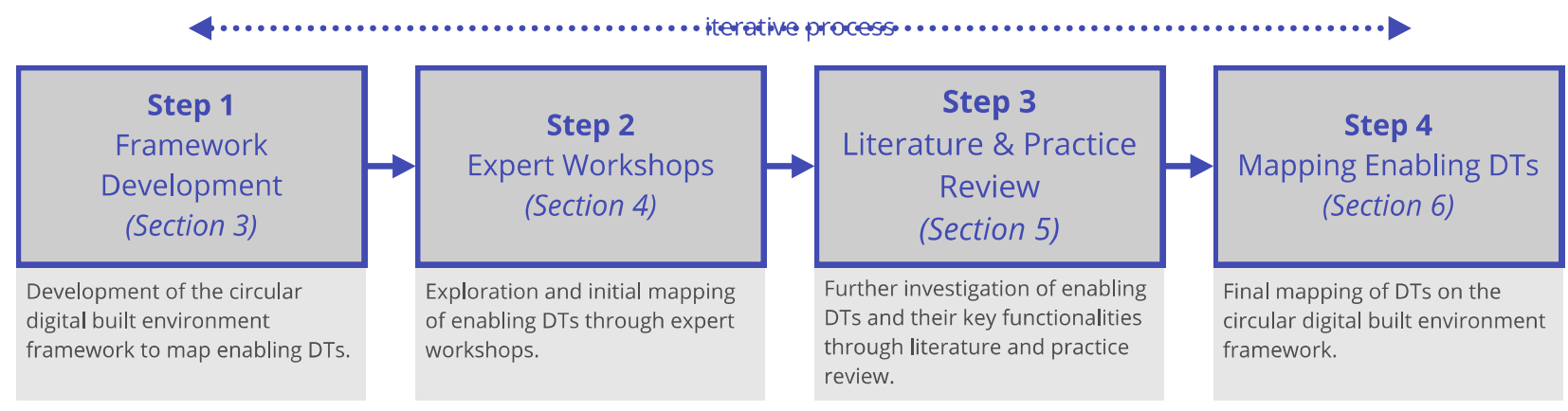

Figure 2. Research design.

\subsection{Step 1-Framework Development}

In order to map the enabling DTs, the CDB framework was developed, similarly to $[31,34,35]$, based on life cycle stages and circular building strategies. For the former, we looked at the life cycle stages of different resource loops-i.e., water, land, energy and materials-and combined them with the building project development stages. Eventually, three overarching life cycle stages are considered: the pre-use phase, the use phase, and the next-use phase. For the latter, we reviewed academic and grey literature on circular building and business model strategies, and categorised them under four core CE principles: (1) regenerate, (2) narrow, (3) slow, and (4) close. These core principles were built on previous research [16-18]. In the meantime, we created a list of potential enabling DTs for a circular $\mathrm{BE}$ to be used at the next stage. After the expert sessions, the framework was updated and used for the final mapping of enabling DTs. Section 3 explains the framework development process in detail.

\subsection{Step 2-Expert Workshops}

In the second research step, we conducted three workshops with 16 experts in March 2021. The purpose of the expert workshops was threefold: (1) to explore potential enabling DTs; (2) to map the identified DTs onto the framework; and (3) to find out whether the framework needs further revisions. The two main criteria for the selection of the experts were: having significant built environment industry or academia experience and having worked in circular building projects or developed digital construction tools (preferably for circular construction). Table 1 presents the occupational background, professional experience, and the field of expertise of the participating experts. All of the experts came from Europe. We initially sought professionals with skills in both DTs and circular BE fields. However, it was difficult to find both types of expertise in one person (only three out of the 16 participants had expertise in both fields). Thus, the expert groups were formulated from three pools-experts in $\mathrm{CE}$, circular BE or digital construction technology—by ensuring that at least one from each pool was present in each session. 
Table 1. Overview of the participating experts. CE: Circular Economy in general; CBE: Circular Economy in the built environment; DCT: Digital construction technologies.

\begin{tabular}{|c|c|c|c|}
\hline Groups & Occupational Background & Years of Experience & Field of Expertise \\
\hline \multirow[t]{5}{*}{ Workshop 1} & Academic & 20 & Design and construction management \\
\hline & Practitioner & 25 & $\mathrm{CE} ; \mathrm{CBE}$ \\
\hline & Practitioner & 10 & DCT \\
\hline & Academic & 20 & DCT \\
\hline & Practitioner & 40 & DCT \\
\hline \multirow[t]{6}{*}{ Workshop 2} & Academic & 10 & DCT; Biomaterials \\
\hline & Practitioner & 20 & CE; CBE; Waste management \\
\hline & Architect/Practitioner & 25 & $\mathrm{CE} ; \mathrm{CBE}$; Reversible building design \\
\hline & Academic & 15 & DCT; Sustainable design strategies \\
\hline & Architect/Practitioner & 32 & CBE; Design philosophy \\
\hline & Practitioner & 15 & $\mathrm{CE} ; \mathrm{CBE}$ \\
\hline \multirow[t]{5}{*}{ Workshop 3} & Consultant & 15 & CE; CBE; DCT \\
\hline & Practitioner/Consultant & 17 & CE; CBE; DCT \\
\hline & Engineer & 14 & DCT; Prefab timber system design \\
\hline & Academic & 16 & $\mathrm{CBE}$ \\
\hline & Consultant & 15 & CE; CBE; DCT \\
\hline
\end{tabular}

Prior to the workshops, the experts were given information regarding the research and workshop protocol and were asked to mention enabling DTs for a circular BE. This input was then used to update the preliminary list of enabling DTs, which was presented to the participants during the online sessions. All of the sessions were organised online through a video conferencing platform and took approximately $60 \mathrm{~min}$. An online interactive whiteboard application was used to record the experts' input on the framework. The primary researcher facilitated the sessions and took field notes. These notes are reported as a summary of each workshop in Section 4 . The following workshop procedure was followed in all of the sessions:

- Introduction [10 min]: Upon welcoming the participants, the primary researcher briefly introduces the workshop's goal and explains the main elements of the CDB framework. The participants are allowed to add notes and suggest new circular building strategies or enabling DTs.

- Questions and Discussion [45 min]: The researcher poses a set of questions: "What DTs can enable CE in the BE? Where would you place them on the framework?" and initiates discussions when needed.

- Closing [5 min]: The researcher receives feedback from the participants and closes the session.

\subsection{Step 3-Literature and Practice Review}

In the third step, we conducted a literature and practice review to determine the ways in which the identified DTs enable a circular BE. For the literature review, we used the Scopus database and searched for articles using a number of search strings. The scope of the search was limited to articles that explicitly referred to "circular economy". We also included subfields of some DTs. For example, when searching for articles relating to Artificial Intelligence, we used the following search string: "circular economy" AND (AIOR "artificial intelligence" OR "machine learning" OR "deep learning") AND ("construction" OR "building" OR "built environment"). See Appendix A for the search strings used in the literature review.

The initial query resulted in 265 articles and conference proceedings as of March 2021 (no timeframe was applied). However, the articles containing terms and expressions which were semantically different but homonyms (e.g., "construction" is used as "model construction") were eliminated. This led to 77 relevant articles, which were then analysed to select the ones that demonstrate a structured relationship between the DTs and circular building strategies. We excluded papers that were too broad in scope and which did not give a clear indication of DTs' enabling functionalities. The resulting papers were then used to map DTs onto the CDB framework. 
To complement the literature review, we also reviewed practice, similar to [18], and made use of pertinent literature beyond CE, e.g., energy efficiency in buildings. The purpose of the practice review was to exemplify the applications of enabling DTs in real-life. We used two search engines, Google [57] and Ecoasia [58], and reports from consultancy firms (e.g., ARUP) to retrieve the examples. However, it was not possible to find examples for all of the DTs, as some of them are studied at the theoretical level by academics.

\subsection{Step 4-Mapping of Enabling Digital Technologies}

In the last step, we synthesized the findings from the preceding steps and mapped the enabling DTs onto the CDB framework in order to better understand how DTs relate to the circular BE. The final mapping of the DTs was based mainly on the literature and practice review findings whereby the main trends observed during the expert workshops were incorporated. Table S2 in the Supplementary Materials presents the references used in the CDB framework in detail.

\section{Framework Development}

\subsection{Life Cycle Stages}

The BE consists of several interconnected sub-systems (e.g., cities, infrastructure, buildings) which are exposed to varying degrees of use [59] and numerous actors [44,60]. Within each system, multiple resources coincide, including material, land, energy, water and nutrients (from here onwards, 'resource' is used to refer to all). These resources have different characteristics, functions and lifespans (See Figure 3); therefore, their recovery in a circular system requires individual attention [60]. Moreover, buildings are exposed to a large number of stakeholders from the design until the end-of-life stages, such as architects, developers, occupants and demolishers [61]. The number, combination, and timeframe of the stakeholders vary by project as each building is considered a unique entity [44].

Given the complexity of buildings and their associated resources, it can be acknowledged that simplifying the life cycle stages for the framework development is a challenging task. The commonly used building life cycle stages consider four main phases: the production stage, the construction process, the use stage, and the end-of-life stage (see, for example, European standard EN 15978:2011 [62]). This approach is based on material flows and the associated water and energy consumption and overlooks the "design process" which is a fundamental phase for developing circular buildings where DTs play a critical role. A recent review article highlighted that project design was the second most considered life cycle stage in circular BE research [63]. Therefore, in our framework we also include the design stage in buildings' life cycle stages. Overall, as illustrated in Figure 3, we consider three main lifecycle phases by taking into account the material [27], water [64-66], energy [67] and land [68] cycles: the pre-use phase, the use phase, and the next-use phase.

The pre-use phase concerns activities that take place before buildings are occupied by users. These activities include mining raw materials or reclaiming resources from existing buildings, manufacturing building components, design, transportation, and construction or assembly. Depending on the construction method, the order of these activities may change. The pre-use phase activities play a critical role in reducing the resource inputs and increasing the operational performance of buildings, leading to a lower carbon BE. The use phase often constitutes the longest period of a building's life cycle, when a significant environmental impact is created $[67,69]$. Therefore, it is very crucial to design buildings in such a way that their operational performance is also optimised. In addition, the use phase is critical to extending the lifetime of buildings and building products by activities such as repair and maintenance. Finally, the next-use phase refers to reintroducing buildings and associated resources when they reach their end-of-use stage. We envision a circular system in which there is no end of life; instead, all of the resources are reintroduced to the system multiple times by reuse or recycling with minimum resource inputs (see Section 4 for further arguments on this topic). 


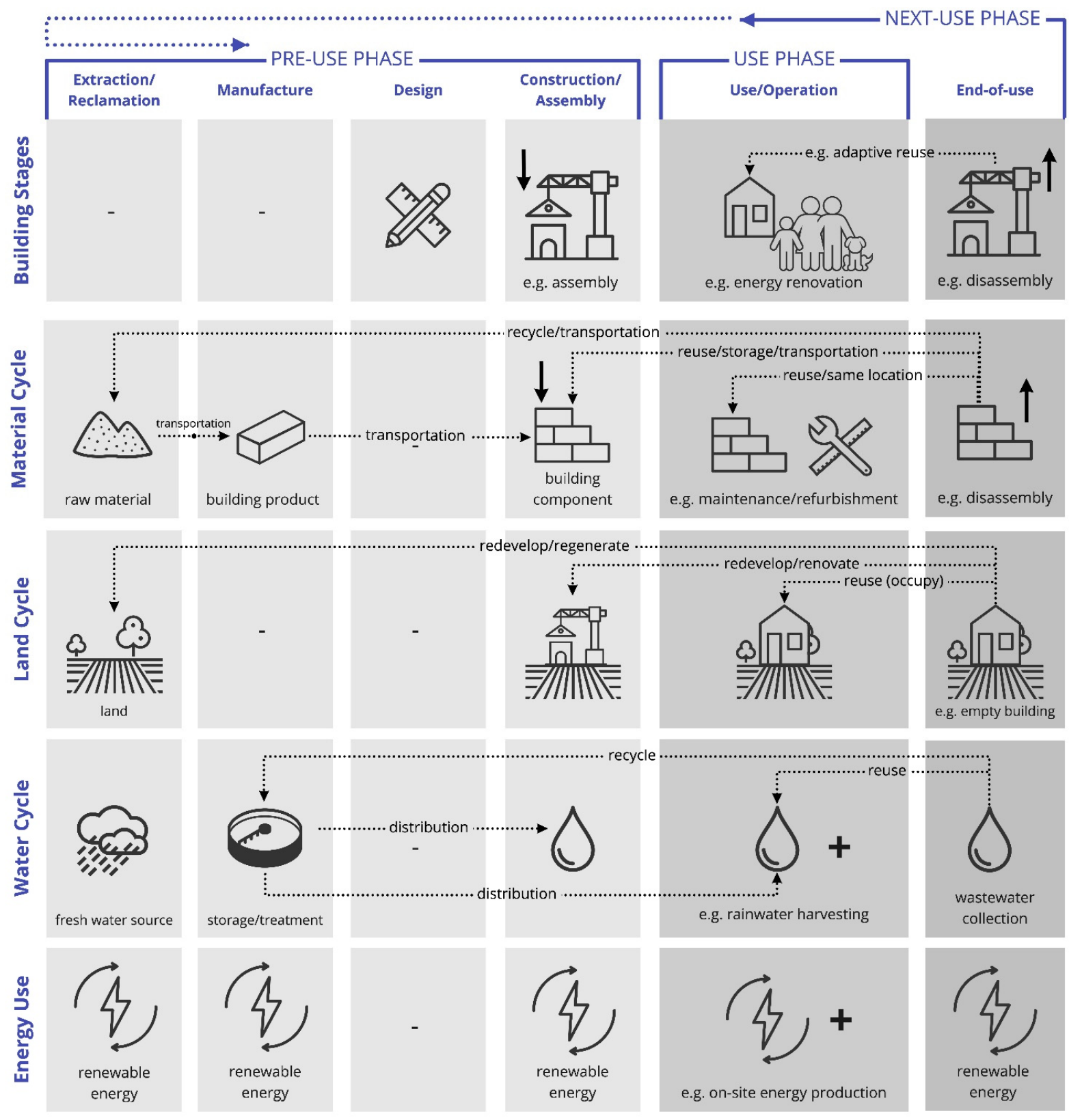

Figure 3. Life cycle stages in a circular built environment (Own illustration). Note: The life cycle stages of resources are shown in a simplified way. The resource cycles were built on previous research $[27,64-68]$. "+" signs on the water and energy cycles indicate potential surplus resource production.

\subsection{Circular Building Strategies}

$\mathrm{CE}$ is an emerging concept in $\mathrm{BE}$ research that has received significant recognition in the past decade $[63,70,71]$. Scholars have focused on various research areas from material reuse to urban planning [71], in which end-of-life activities, e.g., waste management, were the central issue in most of the studies $[63,70,71]$. As noted by [70], a holistic evaluation of CE principles that embrace all of the life cycle stages of buildings is missing. Several comprehensive framings of circular strategies have been proposed for building components [72], prefabricated buildings [73], industrialised housing construction [74], new building design and construction [60], sustainable building construction [70], material and product flows in buildings [75], and CE in the real estate sector [76]. These frameworks look at either one particular life cycle stage (e.g., the design phase) or production method (e.g., prefabrication), or consider a specific resource flow (e.g., the material flow), lacking a holistic approach. 
By building on previous research, we propose a comprehensive approach to group existing circular building strategies under four core CE principles [16-18]: regenerate, narrow, slow, and close resource loops. We also add "collaborate" as a supporting strategy to address the inefficiency issues in the construction supply chain, which are fundamental in transitioning towards a circular BE. The following sections elaborate on the details of each principle and the associated circular building strategies.

\subsubsection{Regenerate}

The terms "regeneration" and "restoration" are frequently used in CE definitions interchangeably; however, their meanings were poorly discussed [77]. In technical cycles, products are reintroduced to the economy through restorative activities such as repair and remanufacturing [77], while regeneration aims to upgrade the state of systems by pursuing a net positive impact on the environment [16]. In architectural design, regenerative design is believed to be the highest level of sustainability, going beyond green and sustainable building concepts, generating continuous flows of resources in a self-sufficient manner $[78,79]$ in which co-evolutionary systems are initiated between humans and nature based on the characteristics of the place [80]. It shifts the mindset from "doing things to nature" to "being part of nature" [81]. Within the scope of this study, we consider regeneration as one of the core principles of a circular $\mathrm{BE}$, which aims at creating a positive impact in human and natural systems by co-creating with local communities and using renewable and healthy resources. The following strategies are proposed:

- "Stimulate human nature co-habitation and local biodiversity": This is the creation of shared spaces where humans interact with each other and with nature, accommodating green space and promoting biodiversity $[78,82,83]$. Examples include urban farming [84] and green roof ecosystems [85]. A real-life project is Resilio [86], which implements blue-green roofs in Amsterdam.

- "Use healthy and renewable resources": This strategy consists in avoiding hazardous contents in building products [78]; using bio-based renewable building materials, for instance, using mycelium (the vegetative structure of fungi) to produce building components [87]; and producing with renewable energy [18]. For example, the British start-up Biohm is producing insulation panels from mycelium [88].

- "Enhance the indoor and outdoor environment": This strategy includes providing high-quality healthy spaces for people in terms of lighting, air and place organisation [78,83], and enhancing outdoor space, i.e., public and urban areas. An example is the transformation of misused or unused areas (wastescapes) into public spaces for local communities [68].

- "Exchange excess resources": This strategy includes capturing economic value from regenerative building operation. Positive buildings are equipped with advanced technologies that allow them to share surplus resources with their surroundings (energy, water, food and others) [82]. Particularly for energy, the recent years have seen tremendous advancements in smart grid technology that allow prosumers (consumers who also produce and sell energy) to trade surplus energy within their neighbourhoods [89]. An example is Pando [90], a platform that empowers users to buy and receive local renewable energy within their neighbourhoods through a mobile application.

\subsubsection{Narrow}

As described in [17], narrowing resource flows refers to resource efficiency and the use of fewer inputs in products. Translating this to the circular BE, 'narrow' indicates the use of fewer resources throughout a building's lifetime. In that sense, the early design phase plays a critical role, as design decisions influence the performance of buildings and their operations in later stages $[43,74]$. Furthermore, upgrading the systems in existing buildings might lead to reductions in water and energy consumption during the use phase. Narrowing strategies are summarised into three groups: 
- "Reduce primary resource inputs": This strategy is based on the dematerialisation approach [74,91]; it aims to minimise the primary resource inputs in buildings and building products. Some examples include optimising lightweight structures [92], using renewable energy in production, designing water circulation systems for sanitary hot water [66], and avoiding extra rooms in the space planning by assessing their added functions [75], i.e., avoiding the second bathroom. Designing from reuse rather than with new materials is also another way to reduce primary resource inputs.

- "Design for high performance": This design strategy aims to optimise the building performance for fewer resource consumption before, during and after the use phase of buildings. For instance, by considering building characteristics such as geometry, the site, materials, and orientation, design optimisation provides considerable energy savings during the operational phase [69,93]; by optimising the transportation distance, resource consumption could be reduced during the construction and end-of-use stages.

- "Improve efficiency": This strategy includes enhancing the pre-use, operational, and next-use phase activities for lower resource consumption, such as improving manufacturing systems for high performance, introducing rainwater collection systems in existing buildings or upgrading the building facade for higher energy performance. For example, the Rennovates project implemented a technology-based renovation concept in 249 old single-family houses and upgraded their energy performance to the zero-energy level [94].

\subsubsection{Slow}

The slowing resource loops principle intends to slow down the speed of resource flows by intensifying their use and extending their valuable service life $[13,17]$ through design and operational strategies, as listed below:

- "Design for long life": Originally introduced for short-lived consumer products, e.g., mobile phones [17], design for long-life aims to extend the utilisation period of buildings and building products. This can be achieved by creating an emotional connection with users [17], increasing the physical durability of building components [60], and considering the ease and frequency of maintenance work during the design phase [95], i.e., considering easy access to technical building services [60].

- "Design for reversibility": Reversible building design incorporates several design strategies that enable multiple resource life cycles until resources become irreversible. The circulation of resources occurs on the spatial, structural and material levels, and it has two main domains [59]: (1) spatial reversibility refers to the ability to functionally transform spaces without causing significant resource consumption, e.g., transforming an office into a classroom, while (2) technical reversibility addresses how structural and material arrangements are made to allow the reuse of building parts in the future, e.g., designing interlocking connections between components so that they can be easily dismantled [59]. The set of strategies that enable reversibility include design for disassembly, design for reuse, modular design, flexible design, adaptable design, design for standardisation, design for upgrades and adjustment, prefabrication, and off-site construction. An example of a reversible building design is the UMAR (Urban Mining and Recycling) project built for disassembly in Switzerland [96].

- "Lifetime extension": This strategy targets the use phase of buildings and is concerned with prolonging the service life of buildings and building products through predictive, preventive or reactive maintenance and repair $[17,35]$.

- "Smart use of space": The main purpose of flexibility and adaptive reuse strategies is to capture value from the existing buildings or land by introducing new functions; otherwise, they will remain underutilised and lose value. These strategies might exist in different forms, including the transformation of vacant office spaces into housing units [97]; the modification of the building lay-out for a different function [59]; the retrofitting, rehabilitation and redevelopment of cultural heritage buildings [98]; building modular buildings temporarily on a vacant land [99]; and the short-term 
utilisation of empty spaces through lease agreements [99]. An example is Workfrom, an online platform that lists available cafes, co-working spots and alternative spaces for users, making use of under-occupied spaces in cities [100].

- "Deliver access and performance", or, more broadly, Product-Service Systems: This business model strategy is focused on providing services instead of the ownership of products $[17,30]$. This could be achieved in three ways: (1) the customer receives services based on time use (use-oriented), (2) the customer pays for a contractually-set performance or outcome (result-oriented), (3) the customer keeps the ownership of the product but receives high warranty and maintenance services (product-oriented) [30,101]. (NB: the latter is an example of a Product-Service-System where the product is still owned). Examples include co-working spaces which provide workplaces for enterprises as a service, or Signify's pay-per-lux model for lighting [102].

- "Reuse": Reuse is concerned with reintroducing buildings and resources back into the system without needing major transformation and resource consumption. Reuse may occur in the same or a different location, and the function of the product may remain or change [27]. Strategies such as 'reduce primary resource inputs', 'design for reversibility', 'smart use of space' and 'urban mining' are partially built on reuse. Reuse as a separate strategy can also go beyond these strategies, e.g., reusing greywater in buildings [66] or reusing old window frames to construct an indoor partition in the same place during a façade renovation.

\subsubsection{Close}

The closing resource loops principle aims to bring resources back into the economic cycle when buildings reach their end-of-use stage. Within the context of BE research, four closing resource loops strategies can be seen at the end-use-phase:

- "Recycle": Recycling is concerned with remanufacturing resources into equivalent or lower-value resources, and usually requires energy and water for the processes (e.g., glass melting) [27]. This strategy has been dominantly used in BE for treating construction and demolition waste, e.g., recycling concrete aggregates [103]

- "Urban mining": Heisel and Rau-Oberhuber define urban mining as "the re-activation of materials accumulated in the urban environment, which were not specifically designed for re-use or recycling (thus mining)" ([96], p. 2). The process requires the identification, quantification, and mapping of materials in cities and determining their recycling potential [104]. Urban mining in practice can be seen in the Dutch city of Rotterdam, which has the goal of reducing primary resource use by $50 \%$ before 2030 [105]. The municipality of Rotterdam identified and mapped buildings that are scheduled to be demolished in order to harvest materials in the future [105].

- "Industrial symbiosis": Industrial symbiosis is a concept to benefit from the waste or by-products of different industries by building collaboration and synergetic interactions [106]. For example, researchers demonstrated an industrial symbiosis model between a recycling factory and a concrete production factory based on recycled concrete aggregates [106].

- "Track and trace resources": Tracking and tracing resources throughout the lifetime of buildings enables us to capture embodied value when they reach their end-of-use phase.

\subsubsection{Collaborate (Supporting Strategy)}

A higher degree of collaboration among supply chain actors is needed to achieve circularity in the BE. The construction industry is known for its highly fragmented and inefficient nature [43], which was seen as one of the major barriers in CE transition [61]. Therefore, we propose two collaboration strategies to support the circular transition of the BE:

- Support supply chain collaboration: The first level of collaboration may occur at the level of single materials and technologies and reverse logistics, e.g., to reclaim building materials in a demolition project, or to implement a new technology [107] in 
a new-built project to increase energy efficiency. This can be done mainly within the existing supply chain network without too much disruption.

- Create knowledge and value networks: The more transformative CE projects start with an ambitious vision of the future [61,107] that may require different types of partners to regenerate, narrow, slow, and close the loops. These partners would share the same vision, bring in new experience, and also support the creation of a new circular ecosystem. A wider sector-engagement is also needed for a broader transition in the sector [107], and there is evidence for such engagement already. For example, a buyer group initiative was established by the contracting authorities in the public and private sector to stimulate circular procurement in the Netherlands [108].

A summary of the circular building strategies and examples is given in Table 2.

Table 2. Summary of the circular building strategies and examples.

\begin{tabular}{|c|c|c|}
\hline Core Principle & Circular Building Strategy & Description and Example \\
\hline \multirow{4}{*}{ Regenerate } & $\begin{array}{l}\text { Stimulate human nature } \\
\text { co-habitation and local } \\
\text { biodiversity }\end{array}$ & $\begin{array}{l}\text { Create spaces for human nature interaction and biodiversity, e.g., green roof project } \\
\text { in Amsterdam [86]. }\end{array}$ \\
\hline & $\begin{array}{l}\text { Use healthy and renewable } \\
\text { resources }\end{array}$ & $\begin{array}{l}\text { Eliminate toxic contents, use bio-based materials, and produce with renewable } \\
\text { energy, e.g., producing insulation panels from mycelium [88]. }\end{array}$ \\
\hline & $\begin{array}{l}\text { Enhance indoor and outdoor } \\
\text { environment }\end{array}$ & $\begin{array}{l}\text { Improve the indoor environment and regenerate degraded outdoor spaces, e.g., } \\
\text { transformation of misused urban areas into public spaces [68]. }\end{array}$ \\
\hline & Exchange excess resources & $\begin{array}{l}\text { Exchange surplus resources produced by regenerative buildings, e.g., exchanging } \\
\text { renewable energy within the neighbourhood [90]. }\end{array}$ \\
\hline \multirow{3}{*}{ Narrow } & Reduce primary resource inputs & $\begin{array}{c}\text { Minimise primary resource use and waste, e.g., optimisation of lightweight } \\
\text { structures [92]. }\end{array}$ \\
\hline & Design for high performance & $\begin{array}{l}\text { Optimise buildings and systems for fewer resource use, e.g., early design } \\
\text { optimisation for passive performance [93]. }\end{array}$ \\
\hline & Improve efficiency & $\begin{array}{l}\text { Enhance performance of building systems and operations to minimise resource } \\
\text { consumption, e.g., deep energy renovation of old houses [94]. }\end{array}$ \\
\hline \multirow{6}{*}{ Slow } & Design for long life & $\begin{array}{l}\text { Design buildings with durable materials, consider ease of maintenance and repair, } \\
\text { and design for emotional attachment. }\end{array}$ \\
\hline & Design for reversibility & $\begin{array}{l}\text { Design buildings and products for multiple life cycles with deconstruction and } \\
\text { transformation strategies, e.g., the UMAR Project [96]. }\end{array}$ \\
\hline & Lifetime extension & $\begin{array}{l}\text { Extend the service time of buildings and components by restorative activities such } \\
\text { as repair, maintenance and refurbishment. }\end{array}$ \\
\hline & Smart use of space & $\begin{array}{l}\text { Deliver new functionalities to underutilised buildings, and land through adaptive } \\
\text { reuse and flexibility, e.g., flexible office spaces [109]. }\end{array}$ \\
\hline & Deliver access and performance & $\begin{array}{l}\text { Provide access, functionality or services without offering ownership of buildings } \\
\text { and building products, e.g., pay-per-lux model for lighting [102]. }\end{array}$ \\
\hline & Reuse & $\begin{array}{l}\text { Bring resources back into the economy with a minimum of resource input, e.g., } \\
\text { construct indoor partitions from old windows during façade renovation. }\end{array}$ \\
\hline \multirow{4}{*}{ Close } & Recycle & $\begin{array}{l}\text { Convert reclaimed resources into similar or lower quality ones with considerable } \\
\text { energy and water input, e.g., recycling concrete aggregates [103]. }\end{array}$ \\
\hline & Urban mining & $\begin{array}{l}\text { Extract materials from the urban environment that are not designed for reuse or } \\
\text { recycling, e.g., urban mining project in the city of Rotterdam [105]. }\end{array}$ \\
\hline & Industrial symbiosis & $\begin{array}{l}\text { Initiate synergistic interactions between different industries to recover waste and } \\
\text { by-products, e.g., an industrial symbiosis for recycled aggregates [106]. }\end{array}$ \\
\hline & Track and trace resources & $\begin{array}{l}\text { Track and trace resources from extraction/reclamation until end-of-use stages and in } \\
\text { further cycles. }\end{array}$ \\
\hline \multirow{2}{*}{$\begin{array}{l}\text { Collaborate } \\
\text { (as supporting } \\
\text { strategy) }\end{array}$} & $\begin{array}{l}\text { Support supply chain } \\
\text { collaboration }\end{array}$ & $\begin{array}{l}\text { Work with partners in the existing supply chain to slow, close, narrow and } \\
\text { regenerate resource loops, e.g., for reverse logistics. }\end{array}$ \\
\hline & $\begin{array}{l}\text { Create knowledge and value } \\
\text { networks }\end{array}$ & $\begin{array}{c}\text { Identify and develop new networks for collaboration to implement ambitious CE } \\
\text { visions, e.g., a buyer group is established to foster circular procurement in the } \\
\text { Netherlands [108]. }\end{array}$ \\
\hline
\end{tabular}




\subsection{Circular Digital Built Environment Framework (CDB Framework)}

By combining the literature findings presented in Figure 3 and Table 2, we developed the Circular Digital Built environment framework (CDB framework) to map the enabling DTs for a circular BE. The building life cycle stages are demonstrated on the $\mathrm{x}$ axis, against the circular building strategies on the y axis. Furthermore, potential enabling DTs are presented with colour coding. This framework was used in the expert workshops (next section) and was updated in line with the feedback given by the experts. Figure 4 demonstrates the revised version of the framework.

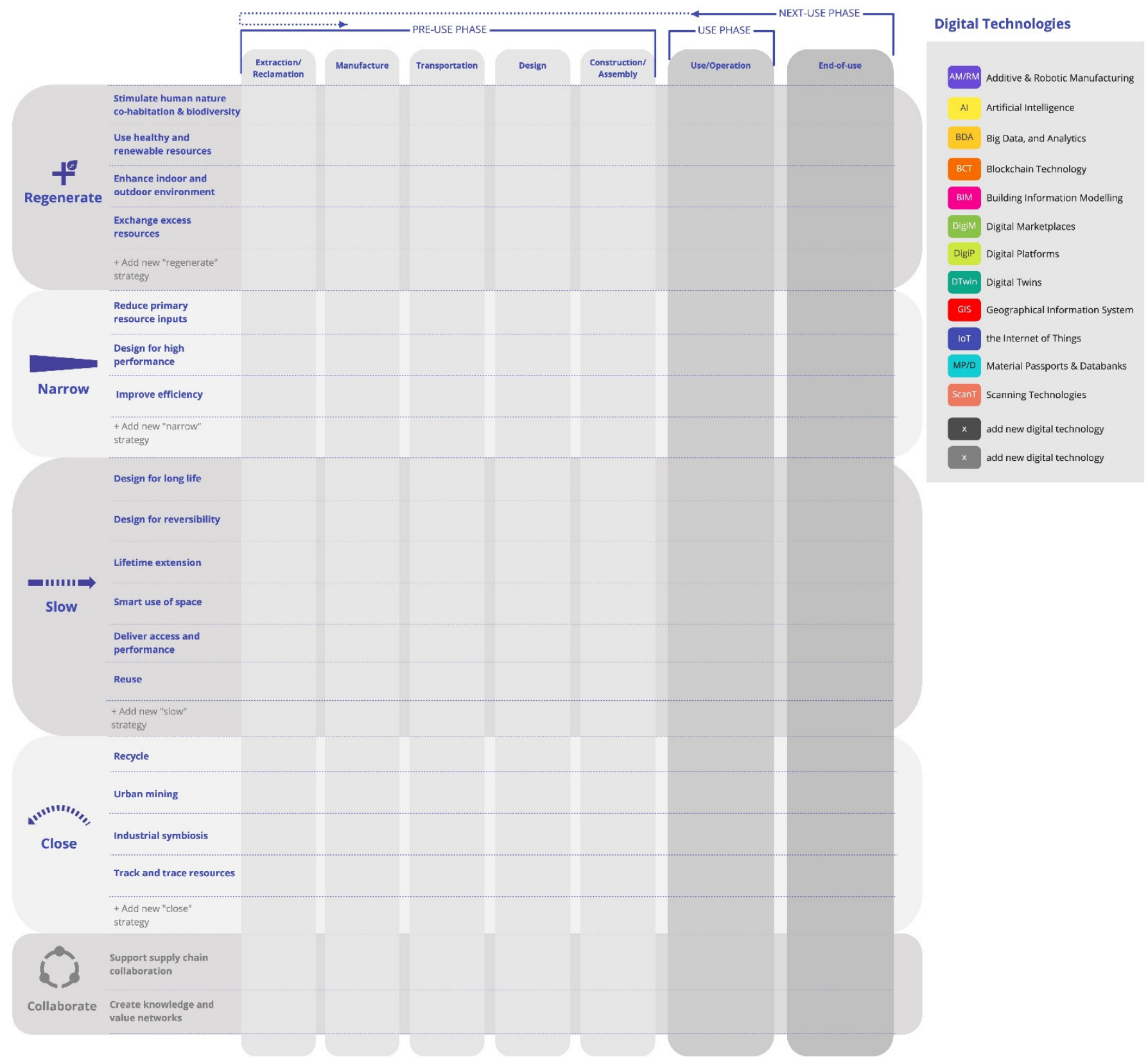

Figure 4. Circular Digital Built environment framework (CDB framework).

\section{Workshop Findings}

The main purpose of the expert workshops was to explore potential DTs for enabling a circular BE, and to map them onto the CDB framework. The experts were given a list of DTs in advance, as shown in Figure 4, and were asked to link the listed DTs with circular building strategies on the framework. Moreover, the experts were allowed to suggest new 
strategies as well as new DTs. In each session, different key discussion points emerged based on the experts' backgrounds. These insights helped us to finetune the mapping of the DTs in the next step.

In the first expert session, the discussions were concentrated on three technologies: BIM, digital twins and digital platforms. BIM is considered to be an essential collaboration tool throughout the entire lifespan of buildings; however, in practice, it is not mature in all of the life cycle stages. Furthermore, the use of digital twins is believed to be an integrative platform on which different technologies are combined to represent the real world at the building, portfolio and urban levels, enabling the monitoring and management of resource flows in the BE. The experts stress the importance of the creation of a platform ecosystem for circular flows of materials. The major challenge for this seems to be the low number of users in both the demand and supply side in current marketplaces.

In the second workshop, the experts discussed the life cycle stages of the framework (the pre-use, use and post-use phases) and suggested the amendment of the "end-of-life" stage to "end-of-use" or "next-use" because, in a circular system, resources have multiple life cycles. Even though buildings reach their end-of-life, the materials embedded in buildings have the potential to be reused in other applications. Another point raised by one of the experts was the missing time dimension. In order to address this issue, the "material availability calendar" was proposed to deliver designers with timely information regarding the availability of materials (See Figure 5). In addition, the experts highlighted the role of parametric design tools in generative building design and their connection with $\mathrm{AI}$ in terms of making sense of large data sets in design practice.
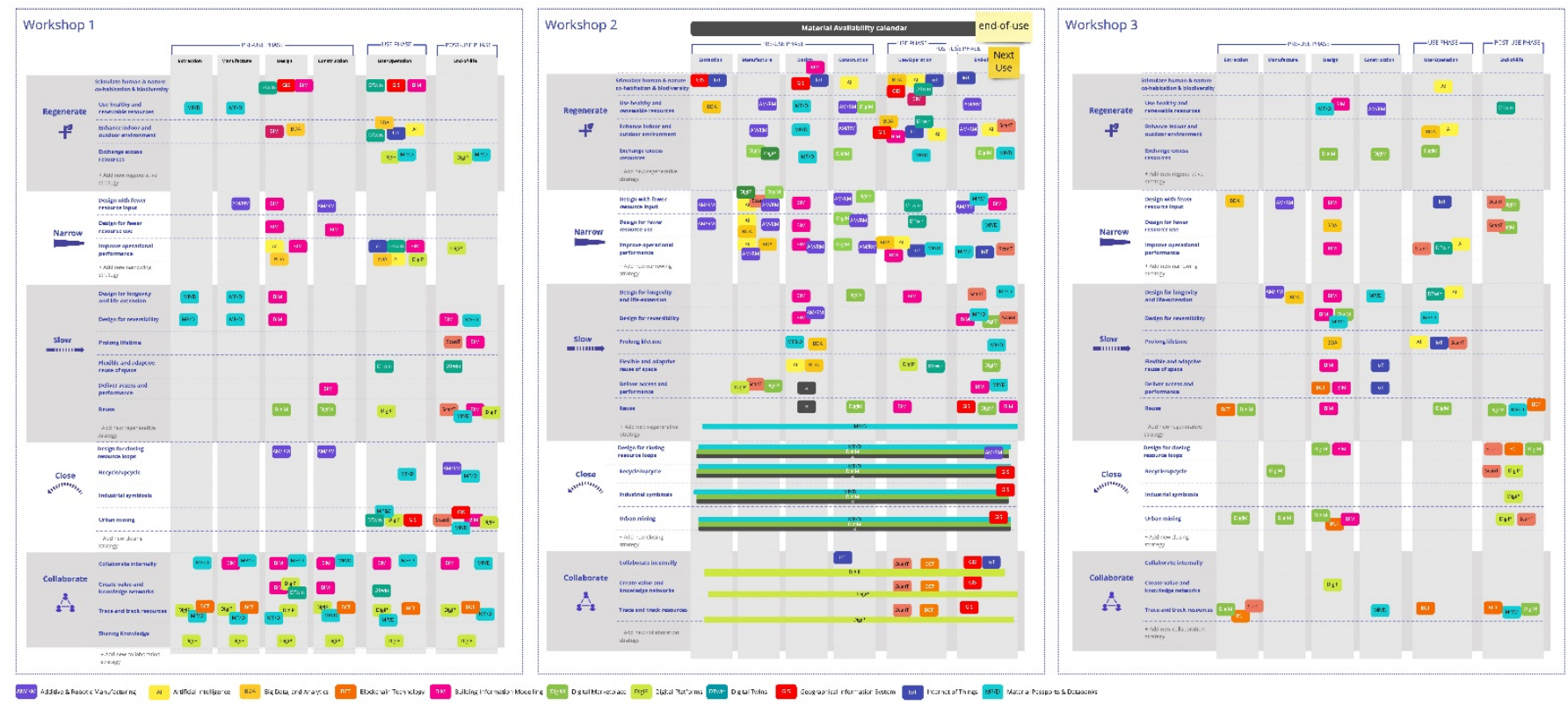

Figure 5. Workshop findings. Note. Full-size versions of the workshop screenshots can be found in the Supplementary Materials.

In the final workshop, material passports were at the centre of attention. Although several material passports have been developed in recent years, uncertainty about data governance seems to be a big obstacle. Compared to digital twins, the current material passport applications remain static in terms of life cycle data management. In that sense, the digital twin concept was found to be important for managing resources in commercial buildings and infrastructure throughout the entire lifetime. Finally, a platform environment was mentioned to be useful for material passports in which all of the parties could communicate from the design until the end-of-use stages. 
The overall impression of the experts on the framework was positive. However, one notable issue was raised in all of the workshops: in most cases, the listed technologies work together, and placing each DT separately on the framework was challenging. We address this issue in Section 6 by illustrating the linkages between different technologies. Furthermore, on top of our list of enabling DTs, no additional DTs were proposed. The experts recommended a few tools, such as simulation and parametric design tools, to support the design process, which are discussed in connection with the identified ten potential enabling DTs (see Section 5).

\section{Enabling Digital Technologies for a Circular Built Environment}

Based on the findings from the previous steps, we identified ten enabling DTs that support the transition of the BE towards a CE. Some tools (e.g., simulation and LCA tools) and supporting technologies (e.g., scanning technologies) are not separately explained as they are briefly discussed in connection to the identified DTs. The following sections present the enabling DTs in alphabetical order by highlighting their potential roles in a circular BE.

\subsection{Additive and Robotic Manufacturing (AM/RM)}

The two main digital fabrication methods discussed in the BE are: additive manufacturing (AM), also known as 3D printing, and robotic manufacturing (RM), or, more broadly, automated manufacturing. AM is a manufacturing technology that enables the fabrication of complex 3D objects by adding materials together layer upon layer [110]. It has been predominantly used to produce parts in various sectors, such as the aerospace and automotive industries, and by product designers to produce rapid prototypes of their designs. Its application in the construction industry mainly concerns concrete printing [52,111] and the fabrication of building components from metals and polymers [112]. RM is a manufacturing technology that enables robots to do part of the work previously done by humans, especially repetitive, dangerous, or precision-requiring tasks, such as assembly, lifting, or welding. It is related to Computer Aided Manufacturing (CAM) and Computer Numerical Control (CNC). In the BE, its main applications are the complex assembly of timber or metal elements $[113,114]$, the digital casting of concrete or plaster $[115,116]$, and precise milling or drilling [117].

Compared to the conventional construction methods, AM/RM provides several opportunities for a circular BE.

- $\quad$ First of all, 3D printing with, e.g., concrete can be used to reduce resource use and waste through design optimization [118-120] and can minimise transportation distance [120,121]. AM/RM from, e.g., lightweight PET material fibre enables both lightweight building structures and the use of recycled materials [122]. Researchers demonstrated the potential energy saving of the digital fabrication of a wall or floor component $[123,124]$. An example from real-life practice is the design of a 3D printed steel bridge that used a software to generate the most material-efficient shape [125].

- Second, AM/RM indeed can be carried out by recycling materials in concrete mixes [120], using mining tailings [52], and reusing (waste) materials [126,127].

- $\mathrm{AM} / \mathrm{RM}$ also allows designers to tailor connection pieces for the reuse of truss and frame elements [128]. The modular design of printed structures enables the reuse of building parts at the end-of-life stage [120]. Digital deconstruction is also being researched, e.g., reversible timber beams can be robotically manufactured and disassembled [129]. Digital reuse is gaining attention in general [130].

- Moreover, AM/RM often provides a safer working environment and reduces injuries on site $[120,121]$, contributing to the well-being of construction workers.

- Finally, the emerging research field of bio-based 3D printing has applications in the construction industry, potentially increasing the regenerative aspect of buildings. Examples include 3D printing with biomass-fungi/mycelium bio-composite materials [131] and other bio-based materials [132]. 


\subsection{Artificial Intelligence (AI)}

Artificial Intelligence (AI) is a broad scientific domain covering a large terrain of fields ranging from general-purpose areas to specific tasks, such as diagnosing diseases [133]. Therefore, many definitions of AI exist. At a basic level, AI refers to "the ability of a computer or machine to mimic the capabilities of the human mind" [134] and consists of several subbranches using different techniques. For example, Machine Learning trains algorithms to learn from data and identify patterns for decision making with minimum supervision, while Deep Learning is capable of training itself for leveraged tasks [135]. Some of the example applications of AI in everyday life are chatbots, face recognition systems, voicecontrolled digital assistants and online language translators.

According to EMF and Google [136], AI capabilities offer a number of opportunities for transitioning to a $\mathrm{CE}$, including design improvement, infrastructure optimisation and the operation of circular business models. Similar AI competencies can also be applicable in a circular BE. We group the enabling functions of $\mathrm{AI}$ and its subfields into three groups:

- With design optimisation, designers aim to find the perfect solution for predefined performance criteria. Data-driven approaches, such as neural networks (a subset of Machine Learning), provide advanced solutions for the generation of multiple design alternatives and the selection of the most optimal design solution [69,137]. For example, researchers developed and tested a machine learning model to support architects during the early design phase, which can predict the total carbon footprint of regenerative building design alternatives [138].

- Combined with other technologies such as big data and IoT, AI techniques and algorithms provide capabilities to predict defects in systems and determine resource needs in buildings. For the former, for example, computer vision detection models reinforced with deep learning techniques are used to detect the state of an asset, learn from past data and predict future failures [137], and for the latter, researchers highlight the capabilities of machine learning algorithms for the prediction of the energy demand of buildings [139]. An example from practice is the FaSA project (Façade Service Application) [140]. The FaSA application maps the current state of buildings and predicts the maintenance requirements of the façade elements with the help of AI, drone and sensor technologies [140].

- $\quad$ AI techniques are also believed to be useful for end-use phase activities. Akanbi et al. [141] developed deep learning models based on national demolition records to predict the amount of recyclable, reusable and waste materials generated from deconstruction and demolition projects [141]. Rakhshan et al. [142] proposed a predictive model using machine learning techniques to estimate and evaluate the economic reusability of structural elements. Furthermore, Davis et al. [143] designed an on-site waste classification system using a deep learning method that can classify different categories of waste based on digital photographs taken from construction site bins. Similarly, other researchers also used deep learning-based image analysis to obtain the composition details of recycled aggregates in order to improve recycling performance [144].

\subsection{Big Data, and Analytics (BDA)}

With the advancement of the internet and digital technology in the last few decades, data generation by people, machines, and their interactions grew tremendously. The term 'Big data' is used to define large data sets which cannot be handled by typical software tools [145]. These data can be found in diverse formats such as text, audio, video or social media [146]. Although the term 'big data' evokes 'size' as its main attribute, other characteristics have also been highlighted recently. For example, the framework of the Five Vs describes five aspects of big data [147]: volume (the amount of data), variety (the heterogeneity of a data set), veracity (the authenticity of the data), velocity (the speed of the data processing), and value. Capturing the value potential of big data lies in translating big data into valuable insights through analytics, as Gandomi and Haider put ([146], 
p. 140): "Big data are worthless in a vacuum". Thus, big data analytics deals with analysing and interpreting the acquired data to extract insights for better decision making [146] by incorporating many techniques such as statistics, data mining, predictive analysis and machine learning [148].

According to Bilal et al. [148], the construction sector has progressed slowly in adopting BDA even though an enormous amount of data is generated throughout the lifespan of a building through BIM, embedded devices and sensors. The authors highlight several opportunities that this technology offers for the sector, which might be considered within the context of the CE: resource and waste optimisation, generative design, performance prediction, personalised services, energy management, BIM and IoT applications, and intelligent buildings. Building upon these, the following roles are identified for BDA in a circular BE:

- Big data are used to train machine learning algorithms for designing low carbon regenerative buildings [138], supporting generative design tools [148], and assisting decision making in design processes [30]. Moreover, data mining techniques are employed for the improvement of buildings' energy performance [149] during the operational phase, leading to the lower use of resources.

- As highlighted by [30], BDA might play a vital role to prolong the lifespan of the products by providing insights into sustainability-oriented decision making during the operational phase. For example, Katona and Panfilov [150] designed and tested a smart maintenance framework on a real-life heating, ventilation and air conditioning unit to detect and prevent failure with the help of sensing technologies and BDA.

- Finally, as we will explain in Section 5.10, together with IoT, BDA are seen as being essential in realizing smart buildings and cities [151].

\subsection{Blockchain Technology (BCT)}

Since the publication of the famous whitepaper 'Bitcoin: A Peer-to-Peer Electronic Cash System' in 2008 [152], Blockchain Technology (BCT) has received significant interest both from academia and in practice. The concept is based on a distributed peer-to-peer system that is cryptographically secured, enabling transparent value transactions without needing central authorities and intermediaries such as banks and government agencies. IBM defines five disruptive elements of BCT [153]: transparency (the end-to-end visibility of the transactions), immutability (records cannot be altered or deleted), security (blockchain is secured by cryptographical techniques making it very difficult to hack), consensus (the consensus of the network participants is needed to validate transactions), and smart contracts (automation of business logic).

Although the initial focus has been on cryptocurrencies, a range of different application areas have emerged, as BCT allows any form of registry, inventory and exchange of tangible and intangible assets [154]. For instance, Hunhevicz and Hall [38] identified twenty-four potential use cases of $\mathrm{BCT}$ in the $\mathrm{BE}$, which include: using smart contracts to automate transactions between external actors, tracking supply chain logistics, timestamping changes in BIM models, recording the ownership of assets, maintaining material passports, and automating building maintenance based on IoT interactions [38]. The following functions were identified for BCT in a circular BE:

- From a CE perspective, BCT is considered to be an enabling technology, particularly for the management of complex information networks in supply chain management $[155,156]$. In a sector that is characterized by low productivity and a fragmented supply chain [38], BCT might offer opportunities to leverage efficiency and transparency to maintain the value of resources along their lifecycle. Li et al. [53] proposed a smart product-service system for prefabricated housing production based on IoT and blockchain technologies. A blockchain system was employed to control the cash flow autonomously through smart contracts, and to perform data exchange between relevant stakeholders acting as a shared database [53]. Another example from the practice is Circularise [157], a start-up operating a blockchain information exchange platform to enable circular 
value chains, which protects the competitive advantage of companies while sharing necessary information with relevant stakeholders [158].

- According to the literature and practice review of Böckel et al. [155], the most frequently mentioned use case of $\mathrm{BCT}$ in $\mathrm{CE}$ is enabling material passports, because the technology offers the transparency and reliability of data flows across the supply chain network [159], from extraction until end-of-use phase, and further in subsequent use cycles. For example, Tata Steel [160], one of the largest steel-producing companies globally, has piloted a material passport system wherein each of the steel components was given a unique identification and registered on a blockchain, allowing the project stakeholders to follow the life cycle data of the steel products [161].

- $\quad$ BCT enables secure peer-to-peer trading networks [159]. This is especially interesting for local renewable energy exchange, in which intermittency is a big obstacle. Mengelkamp et al. [89] demonstrated the concept of a decentralised local renewable energy market based on a blockchain system to address this issue. Their results suggested that BCT offers secure, transparent and cost-efficient energy trading [89]. An example from practice is a community energy marketplace called Pando [90]. Pando empowers users to buy and receive local renewable energy within their neighbourhoods through a mobile application [90].

\subsection{Building Information Modelling (BIM)}

Building Information Modelling (BIM) is the digital representation of a built asset [162], containing relevant information such as the building's geometry, material properties, and quantities of elements [51]. BIM has been used by many actors in the architecture, engineering, and construction sector for various purposes, including design, design visualisation, design optimisation, cost estimation, construction planning, maintenance and facility management. Won and Fan [163] highlighted two major contributions of BIM to sustainable building design: first, the BIM method can reduce inefficiencies in traditional construction processes by allowing integrated project delivery through effective information sharing between all of the project stakeholders; second, it can help optimise building design to reduce natural resource use and waste creation [163]. The use of BIM for CE goes beyond these two main benefits. Charef and Emmitt [162] investigated existing BIM uses in the $\mathrm{BE}$ and revealed their potential to support $\mathrm{CE}$ implementation. Their study showed that all of the current BIM uses influence achieving CE, e.g., structural design directly impacts the disassembly potential of a building. The authors further identified seven new uses of BIM for a circular BE: a digital model for a sustainable end-of-life, material passport development, project database, data checking, circularity assessment, material recovery processes and material banks [162] (see also Section 5.9). Building on these, the enabling functions of BIM are presented below:

- Within the context of sustainable building design, BIM software and extension tools (add-ins) are used for analysing and optimising building performance (e.g., indoor climate, energy, daylighting, site) [164] and for the integration of life-cycle analysis (LCA) into the building design process [165]. Recent studies expand the capabilities of BIM towards early design considerations for slowing and closing resource loops. For example, Akanbi et al. [48] developed a BIM-based tool to predict the reusability and recyclability potential of design alternatives, and [49] proposed a disassembly and deconstruction analytics system to assess the end-of-life performance of building design. Furthermore, Akinade and Oyedele [43] designed an add-in to BIM software using machine learning techniques to estimate the potential construction waste of design alternatives.

- BIM technology can be used from the design until the end-use phase as a model of an asset's whole life cycle [166], in which resource flows can be traced and monitored. During the use phase, BIM is used to operate and maintain assets [167], and to monitor the operational performance of systems [168]. Emerging sensing technologies integrated into the BIM models provide new capabilities to increase system efficiency. 
For example, [169] developed a dynamic BIM model by embedding real-time sensor data and monitoring accurate information from the asset. Although rarely seen, BIM can also be used in deconstruction activities where the digital copy of the building does not exist. To this end, van der Berg et al. [170] demonstrated in a case study that BIM could be used for analysing the existing condition of the site, labelling reusable elements and performing deconstruction planning simulations.

- As discussed in Section 3.2.5, collaboration is believed to be essential in creating circular supply chain networks to narrow, slow and close the resource loops in the construction sector [61]. BIM, as a collaboration platform, brings project stakeholders together for effective information sharing and transparent project coordination [43,51,163,171]. Akinade et al. [43], for example, developed a BIM-based construction waste analytics tool by putting supply chain integration at the core. The tool assists material producers and suppliers in estimating waste creation so that they can consider the environmental impact of their products during the manufacturing phase [43].

- Finally, BIM supports material passports and databanks by providing necessary information regarding buildings and its components. Most of the material passports and databanks reviewed in this study use BIM either as a source of material data or as a platform to operate on (See Section 5.9).

\subsection{Digital Platforms}

Platform concepts, either digital or non-digital, have been discussed from different worldviews and are dispersed across a wide range of fields, making them challenging to study [172]. From the technical perspective, a digital platform is understood as a softwarebased system providing core functionalities upon which derivative applications can be developed, while non-technical perspectives see it as a multi-sided network, matching different groups of users to exchange goods and services [173]. To date, very few studies have focused on digital platforms in the BE. Chan [171] points out two main approaches in BE literature regarding digital platforms: tool-based platforms that target the building production processes, where BIM plays a central role, and collaboration platforms that bring different actors together for better engagement with the BE. From a CE point of view, Konietzko et al. [174] put forward three essential functions that online platforms deliver for narrowing, slowing, and closing resource loops: first, digital platforms act as virtual markets, allowing access to and the exchange of goods; second, they facilitate the operation of product-service systems, enabling data collection for maintenance and repair; third, they empower people to co-create circular products and services. For a circular BE, the following roles are defined for digital platforms:

- By connecting the supply and demand sides, digital platforms facilitate the creation of circular market ecosystems in the BE in two forms: sharing platforms and digital marketplaces. Sharing platforms operate online, giving temporary access to the idle capacity of resources without transferring the ownership [175], as in the case of Airbnb giving temporary accommodation to travellers. For the BE, there are several examples of sharing platforms; for example, the pilot project called 'Vacant Space Finding' [176] allows users to book available spaces in the city of Amsterdam [99]; EquipmentShare [177] allows peer-to-peer construction equipment rental; Workfrom [100] lists cafés and coworking spaces for remote workers. On the other hand, digital or virtual marketplaces allow the exchange of resources between various actors to regain residual value from discarded materials and products. Such platforms might act as business-to-business (B2B), business-to-consumer (B2C) or both, depending on the context in which they operate. An example from the practice of a B2B marketplace is Excess Materials Exchange [178], a cross-industry matching platform for the high-value reuse of materials and waste. Another example of a B2C platform is Enviromate [179], a closed loop marketplace connecting consumers with leftover building materials. 
- Furthermore, digital platforms are used to manage information flows in circular building processes. For instance, Xing et al. [55] designed a cloud-based data exchange platform which connects physical building components with their virtual counterparts through RFID tags, allowing designers to explore reusable products from existing building sites. This platform also serves as a marketplace. Oberti-Paoletti [180] proposed a web-based platform to track raw materials from pre-consumer agricultural waste to be used in private civil construction projects. Madaster is a platform that registers the data of buildings, products and materials, and calculates the circularity index of building projects [47]. See [96] for the implementation of Madaster in a case study.

- Digital platforms also facilitate communication and collaboration between supply chain actors. Yu et al. [106] developed a GIS-based collaboration platform to enable industrial symbiosis between recycled concrete supply chain actors. This platform allows stakeholders to monitor material flows and perform negotiations between each other. With the aim of engaging all of the supply chain actors in the decision-making process of public works, the DECORUM project developed a multi-user platform [181] This platform supports green public procurement by allowing users to assess the circularity and environmental impact of projects, and to develop a marketplace for recycled materials. Finally, other researchers have proposed an interfirm digital platform concept to allow various stakeholders to exchange data throughout the life cycle of a building [45].

\subsection{Digital Twins}

Digital twins give a virtual replica of the physical world and are already commonly used in the automotive, aerospace and process industries to simulate performance. In the $\mathrm{BE}$ sector, digital twins can be used for autonomous decision-making, feedback and control, predictive maintenance and so on [37]. While BIM is a platform for keeping a record of building information, a digital twin works specifically with real-time data fed by sensors analysing the physical asset [182]. Digital twins require data components from BIM or a custom 3D model of the building, along with also Wireless Sensor Network integration and data analytics [183]. The key contribution of a digital twin is its machine learning capabilities [37], driven by the data collected over the lifetime of the building not only by the sensors but also by the simulations run on the model.

- Connecting digital twins to material passports has the potential to extend the service life of building elements through predictive maintenance [184] (see also Section 5.9). Moreover, using digital twins and material passports could also enable the reuse at the building's demolition phase. Chen and Huang [155] and Landahl et al. [185] proposed digital twin platform concepts for the remanufacturing of construction waste or to support design reuse.

- As mentioned in Section 5.10, digital twins could also help manage space to turn buildings into flexible spaces. An example is the EDGE Olympic office building located in Amsterdam [186]. The building has a digital twin that operates on a cloud platform, allowing users to personalise their working environment and use the space flexibly [186].

\subsection{Geographical Information System (GIS)}

"Geographic Information Systems (GIS) are computer-based systems for storing and processing geographic information about sets of locations ... and can be used as a container of maps in digitised form." ([187], p. 252). At a basic level, GIS represents macro-scale external environments by linking attribute data with a location reference [42]. Some examples of its applications include cadastral management, disaster monitoring, infrastructure maintenance, and regional planning" [42]. GIS is also used with BIM for urban data management, energy-efficient building and urban design, optimising the climate requirements of buildings, and tracking 
supply chain and material flows [42]. In line with the capabilities of GIS, our literature findings suggest two enabling roles for GIS:

- An essential opportunity that GIS offers for a CE is the identification, mapping and management of resources embedded in building stocks for future reuse or recycling. For example, Wuyts et al. [188] used GIS analysis to identify vacant houses and their material stock in the city of Kitakyushu in Japan in order to make informed decisions on the future use of resources. Depending on the quality of the vacant housing, the authors considered several reuse strategies that include maintenance, the intensive use of space, repurposing and urban mining [188].

- GIS is also used to support urban mining and industrial symbiosis in the BE. For the former, the scholars employed GIS data sets from municipal or governmental authorities to identify, calculate, and map material stocks in cities [104,188-190]. For example, Kleeman et al. [189] conducted a GIS-based material stock analysis in Vienna; Oezdemir et al. [104] used GIS as an integral tool to develop a resource cadaster of secondary materials in a district of Germany to facilitate urban mining at a regional level; and Verhagen et al. [190] analysed the building stocks and flows based on GIS datasets to present the potential of urban mining in the Dutch construction sector. For the latter, Yu et al. [106] developed a GIS-based supply chain model for industrial symbiosis based on recycled concrete aggregate. They used GIS to demonstrate material flows in a virtual environment where actors share information and monitor traffic information together with vehicle movements [106].

\subsection{Material Passports and Databanks}

One of the biggest obstacles to reusing and recycling resources in buildings is the lack of sufficient information about materials and substances at the end-of-use phase [51,191,192]. Some scholars proposed creating and storing the material content of assets in a digital environment in the early design stage so that the necessary information becomes available throughout the entire lifespan of buildings in order to recover residual value for the economy $[50,51,191]$. One such system is the Material Passports concept. A material passport (also known as a resource passport or an object passport) is a term used to refer to digitally registered data sets of an object describing its characteristics, location, history and ownership status, in a varying level of detail based on the scope in which the material passport is used. Material passports are developed at the urban, building, product and material levels, and are operated on BIM or a platform environment.

At the urban scale, a "resource cadastre" concept was proposed by [104] to map material quantities in a residential area in Germany. Honic et al. [50] developed a BIMbased LCA integrated material passport that can assess the environmental impact of different building design options. The EU-funded project BAMB introduced a digital platform whereby more than 300 material passports are demonstrated at three detail levels, i.e., product, building and instance [193]. An example from practice is Madaster [47]. Madaster is an online platform that offers services for creating and archiving material passports and calculating the circularity level of buildings [47].

In addition, the concept of material databanks has been introduced as an alternative solution to store, manage and share building information for closing resource loops. Cai and Waldmann [192] proposed a new actor in the construction supply chain called a "material and component bank", which organises the transfer of materials from a demolition site to a new construction site. This independent contractor runs a database supported by BIM data whereby material information is kept up-to-date throughout the lifetime of a building [192]. Building on the work of [192], Jayasinghe and Waldman [194] developed a web-based centralized databank that collects information from BIM models of existing and new buildings, allowing users to analyse the stored data for the recyclability and reusability potential of the building components. Similarly, Bertin et al. [195] proposed a materials bank in the form of a database to stimulate the reuse of load-bearing structural elements. 


\subsection{The Internet of Things (IoT)}

The Internet of Things (IoT) is considered to be one of the core Industry 4.0 technologies [31] that "enables information gathering, storing and transmitting be available for things equipped with the tags or sensors" ([196], p. 253). In an IoT environment, things such as smartphones, electronic devices and machines communicate with each other and with users, forming an interoperable network [31] through several other technologies such as Radio Frequency Identification System (RFID), wireless sensor networks and cloud computing [196]. This communication produces a large amount of data which are then analysed with BDA to generate valuable insights for companies [31] (see Section 5.2).

The application of the IoT in a CE is dispersed across various fields covering topics from smart cities to sustainable product lifecycle management [151]. Bressanelli et al. [30], for example, presented the ways in which IoT and BDA support usage-focused business models in the case of a household retailer. Their study identified enabling functionalities for design improvement, product monitoring, lifetime extension, and the improvement of end-of-life activities. Furthermore, Ingemarsdotter et al. [35] designed a framework to categorize IoT-enabled CE strategies and mapped 40 cases from practice on this framework. The authors highlighted that the majority of the cases employed the IoT for efficiency in use (e.g., energy and water preservation) and product lifetime extension (e.g., maintenance and repair) [35]. Building on the CE strategies defined in [35], we introduce five enabling IoT functionalities:

- As discussed in previous sections, the lack of mechanisms to trace the material properties of the existing building stock is a major barrier to reuse. Many scholars proposed the use of RFID and IoT sensors for the digital and physical traceability of building elements in various building lifecycle stages $[53-55,195,197]$. For instance, Turner et al. [54] presented a distributed manufacturing of modular homes in which information flow is achieved throughout every life stage thanks to sensors embedded in the concrete elements. Another application of resource tracking and monitoring through the IoT can be seen in smart building environments, as explained in the next paragraph.

- One of the prominent application areas of IoT in the BE is performance optimisation for preserving resources. Connected devices in buildings can sense, monitor, optimise and control the indoor environment with BDA. For example, Interact [198], an IoTbased lighting system, collects data from the indoor environment through sensors embedded in the lighting system and provides insights into sustainable building operations. Another example from practice is Polder Roof ${ }^{\circledR}$ [199]. Polder Roof ${ }^{\circledR}$ is a green roof system that measures and regulates the rain-water collected on the rooftop with the help of sensing systems and delivers operational insights to the user [199].

- As discussed in Section 5.2, together with BDA, sensor systems help to track, monitor, and control failures [30]; predict the maintenance needs of installations [150]; and enable remote maintenance, repair and upgrades [35].

- IoT technology allows the real-time monitoring of the available space in a given building through smart sensing systems. The Edge, a smart office building, is equipped with around 28,000 sensors, allowing employees to book meeting rooms or workplaces through a user-friendly platform $[109,200]$. With such a flexible workplace organization, it was possible to dramatically reduce the number of workspaces, i.e., 1080 desks allocated for 2850 employees [200].

- IoT capabilities offer a healthier and comfortable indoor environment by controlling heating, ventilation and space conditioning systems. For example, in The Edge smart office building, the users are provided with a mobile application that enables them to adjust the space lighting and indoor temperature [109,200].

- Several studies addressed the role of the IoT in adopting sustainable business models $[30,55,151,201,202]$. Nombre and Tavares [151] referred to the partnership between SEAT and Signify Philips Lighting for a "light as a service" business model and argued that IoT empowered both partners to monitor and control installations, leading to cost 
savings. Other studies highlighted the role of the IoT in service business models [202], buy-and-sell and lease with reuse models [55], and green business models [201].

\section{Mapping Enabling Digital Technologies onto the CDB Framework}

As shown in Figure 6, this section maps the ten potential enabling DTs onto the CDB Framework based on findings from the expert workshops as well as the literature and practice review. The linkages between circular building strategies and DTs were constructed based on two criteria: a DT or its enabling functions (1) must be studied in the literature or implemented in real-life, (2) if it is not found in literature or practice, they must be either assigned to the same spot at least two times in different expert workshops or explicitly mentioned by the experts. Thus, we prioritized the literature findings when mapping potential enabling DTs and displayed additional expert inputs with dashed frames on the framework. It should be noted that the majority of the points that the experts raised were in agreement with the literature and practice review findings (see Sections 4 and 5). Therefore, the influence of the expert workshops on mapping DTs onto the framework was limited. The corresponding literature and practice references can be seen in Table S2 in the Supplementary Materials.

Our findings suggest that $\mathrm{AM} / \mathrm{RM}$ technologies are prominent among regeneration strategies because they are used to design bio-based materials and ease manufacturing with renewable construction materials (e.g., timber). In addition, AI is employed for advanced data-driven regenerative building design, maintaining green facades and easing surplus resource exchange along with $\mathrm{BCT}$ in positive buildings and neighbourhoods.

As for the narrow strategies, AR/RM, BIM and digital marketplaces appear to be crucial for pre-use phase activities. BIM, add-ins and simulation tools are employed for the optimisation of construction and operational performance in later stages, whereas $\mathrm{AR} / \mathrm{RM}$ is believed to be beneficial for the reduction of primary resource consumption when manufacturing building components. On the other hand, digital platforms and marketplaces are essential for substituting with secondary materials and products in the building design stage for value recovery and allowing multiple life cycles. Finally, narrowing resource flows in the operational phase is made possible through smart building technologies. These DTs are able to sense the indoor and outdoor environment (IoT), analyse sensed data (BDA) and operate with or without human intervention (AI) in order to reduce the operational resource use (e.g., energy and water).

The most prominent slow strategy is thought to be "design for reversibility" and is mainly addressed by academic researchers by proposing new methods and tools. These tools usually work on a BIM platform or are developed as a material passport system, and they target the end-of-use phase reusability of buildings and building parts. Our results show that many possibilities exist for reuse: nine out of ten identified enabling DTs are believed to support reuse activities to some extent. In order to prolong the lifetime of buildings and systems through preventive and predictive interventions, a wide range of applications of digital twins, AI, BDA, BIM and IoT have been proposed. These technologies are also used for the smart use of space, and to enable access and performance business models.

For the closing of resource loops, four DTs stand out: material passports, GIS, digital platforms and digital marketplaces. Material passports were mentioned several times as an enabler of the recovery of residual value from existing building stock; GIS was used to enable industrial symbiosis and urban mining concepts at the urban scale; and digital platforms and marketplaces are seen essential for the creation of a market ecosystem for secondary building materials. As for tracking and tracing resources, BCT, material passports, IoT and digital platforms are thought to play an important role. Finally, for supply chain collaboration, various BIM, GIS and BCT applications have been demonstrated, whereas for creating knowledge and value networks, digital platforms are employed. 


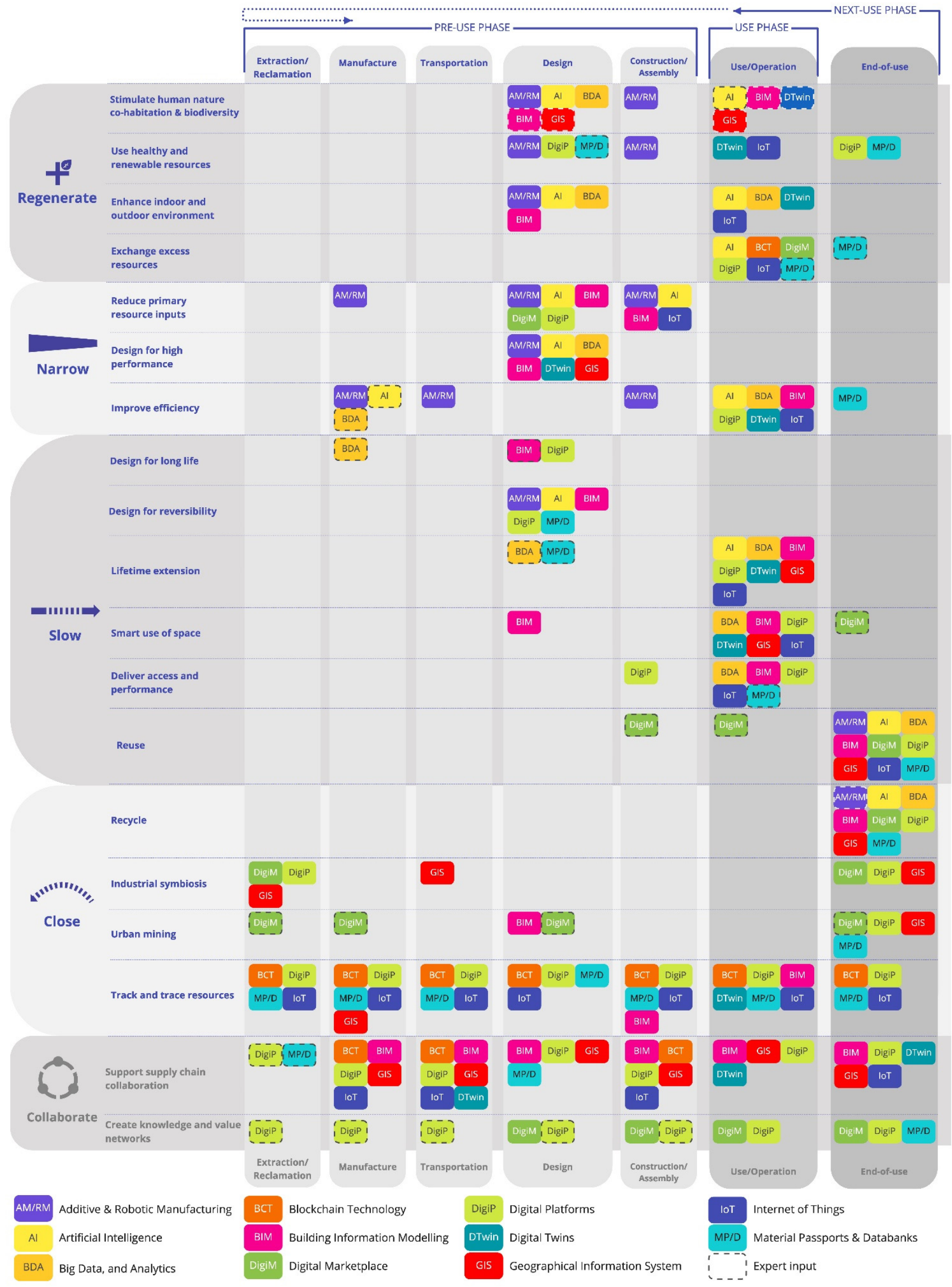

Figure 6. Final mapping of ten potential enabling DTs onto the CDB framework. 
Finally, during the workshops, the experts conveyed that most of the DTs interact with or depend on each other in the course of carrying out a certain task, and that the CDB framework was limited in its demonstration of these interdependencies. In order to address this issue, we illustrated the linkages between potential DTs where we observed them when reviewing articles and real-life examples. Figure 7 gives an overview of the interdependencies among the potential enabling DTs, with references. It is important to note that interactions between DTs demonstrate leveraged capabilities towards achieving CE goals. For example, as in the paper of Xing et al. [55] (highlighted in black dashed lines in Figure 7), material tracking through a BIM-based cloud platform that uses IoT technology enables different stakeholders to exchange information when reusing building components. Their platform has a web interface, connecting potential clients with product owners, which leads to the creation of new business opportunities.

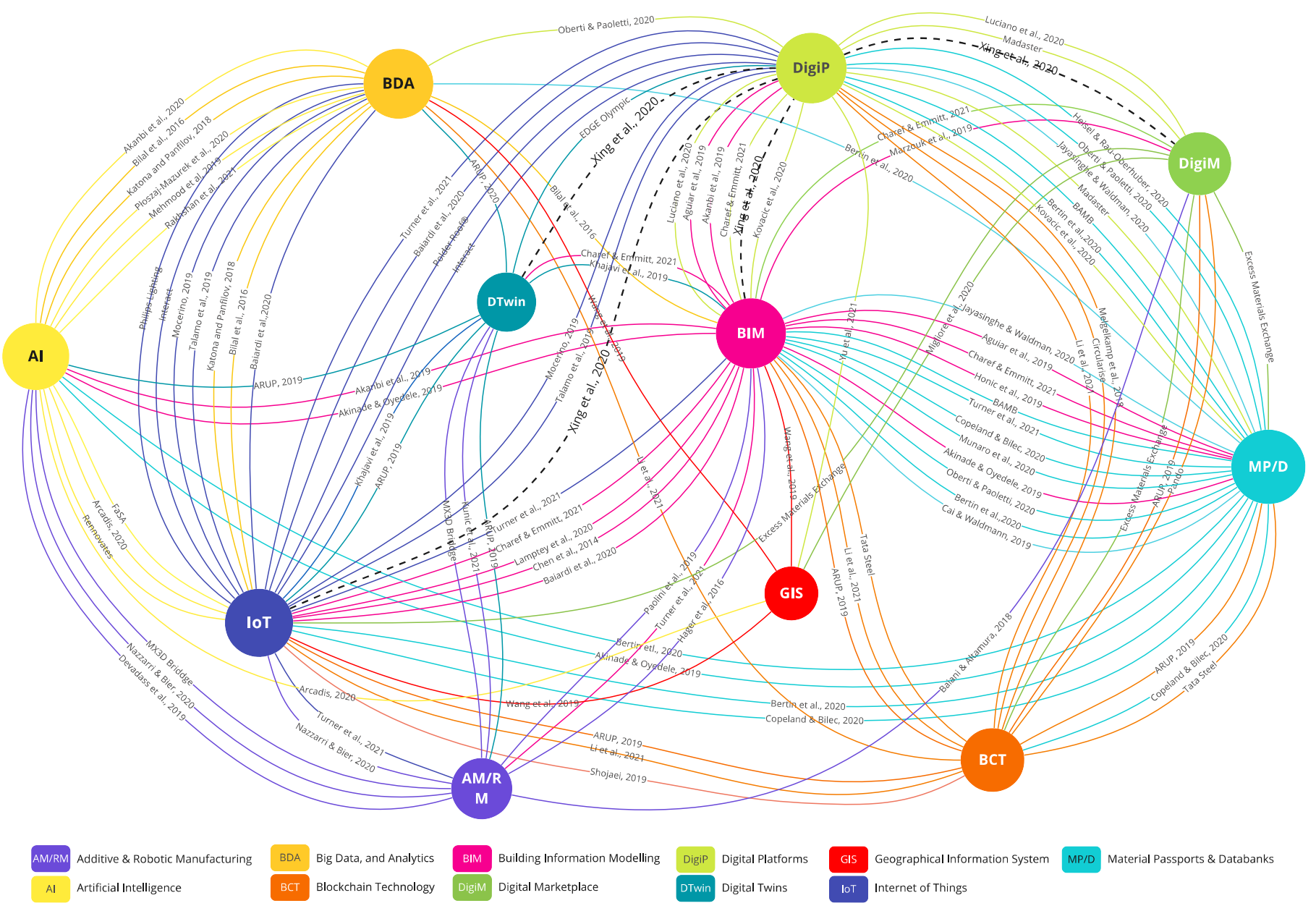

Figure 7. Interdependencies among enabling DTs. The connections between the technologies were mapped based on the literature and practice review.

\section{Conclusions}

\subsection{Discussion of Contributions}

In this study, we have identified ten enabling DTs (AM/RM, AI, BDA, BCT, BIM, digital platforms, digital twins, GIS, material passports and databanks, and the IoT) and explored their potential role in a circular BE across the life cycle stages of buildings. We adopted an iterative four-step method comprising framework development, expert workshops, a literature and practice review, and the final mapping of enabling DTs. Our work contributes to the sparse literature on digital CE for long-lived artefacts (e.g., buildings) and can be considered the first comprehensive framing of the circular digital built environment, 
as far as we are aware. This article makes several significant contributions to the digital CE and circular BE research fields and practice.

First, the CDB framework offers a novel way to categorise the current $C E$ strategies and provides a broad perspective on the understanding of $C E$ in $B E$ research by integrating four core $C E$ principles of regenerating, narrowing, slowing and closing [16-18] with the stages of the buildings' whole life cycle. Our framework extends and complements the previous contributions $[60,70,72,73,75]$ in a number of ways. For example, our consideration of "resource" covers not only materials but also water, land and energy, which is unique, in a way, as there is a tendency to address merely material loops in the circular BE literature. Moreover, we present rarely discussed circular principles such as regeneration in the framework. According to Benachio et al. [63], the most cited $\mathrm{CE}$ definition by the $\mathrm{BE}$ scholars was the one by the $\mathrm{EMF}$, which defines $\mathrm{CE}$ as " . . restorative and regenerative by design ..." ([203], p. 2). However, interestingly, regeneration as a circular building strategy has been predominantly overlooked [76].

Second, the CDB framework provides a comprehensive overview of the potential enabling DTs and explores linkages between novel DTs and circular building strategies. According to our findings from both the expert sessions and the literature review, the prevalent technologies in the current situation seem to be BIM and material passports. The innovations in the other DTs applied to the BE sector have also been explored as potential enablers, which led to the creation of a thorough overview, extending the current practice and research on digital $\mathrm{CE}$ from other industries to the BE industry. For example, on top of the abovementioned two DTs and frequently mentioned Industry 4.0 technologies (AM, $\mathrm{BDA}$, and the IoT) $[30,31,33,34]$, we uncovered AI, BCT, digital platforms, digital twins and GIS, and discussed how they could support various circular building strategies. We also explored how experts interpret these technologies and demonstrated practical examples from real-life implementation.

Third, our work also contributes to the growing body of literature on the enabling capabilities of DTs for a CE. To this end, mapping ten DTs onto the CDB framework aided not only in expanding our understanding of varying functionalities of these ten technologies but also in obtaining a synopsis of which stages in a building's lifetime these DTs could be employed in. The CDB framework, in that sense, provides a valuable starting point for researchers who might be interested in a specific DT or a life cycle stage.

Finally, this paper analyses the intersection of three fields-CE, BE and DTs-by offering an integrative review of these domains. This formulation conceptualises an emerging research field.

\subsection{Implications for Practice}

This research provides practitioners with clear insights into the capabilities of enabling DTs for the realisation of a circular BE in practice. Using the CDB framework, practitioners may create roadmaps for $\mathrm{CE}$ implementation by choosing their circular building strategies and identifying the set of DTs that best support the selected strategies. Furthermore, the framework could be adjusted for a different purpose, e.g., outlining value networks, and could be developed into a tool to further explore circular strategies and DTs by the practitioners.

\subsection{Limitations and Further Research}

A fundamental limitation of this work was the limited number of keywords used when reviewing literature, as we concentrated on the papers that explicitly mention "Circular Economy" in title, keywords and abstract. Further circular strategies and DTs might be discussed in other papers, e.g., because they referred to "reuse" or "resource-efficiency" and interactions with digital technology, without specifically mentioning CE. Although our search focussed on the BE (comprising buildings and infrastructure), we noticed that the majority of the reviewed articles were conducted at the building scale application, as there have been very few examples from other fields, such as infrastructure. 
The second limitation of our investigation was the number and configuration of the expert workshops, as most participants came from Europe, representing a small percentage of the BE industry. Thus, further research is needed to include other perspectives, e.g., from the Global South.

Moreover, our study primarily focused on the enabling functionalities of the listed DTs, rather than the implementation barriers in real-life practices. Furthermore, as most of these technologies are still in the early development phases, the implementation or economic viability is out of the scope of today's practice, as this will evolve throughout the development of the DTs. Especially for the technologies with lower levels of readiness, different forms or combinations can enable the transition to a circular BE. Further research should also cover the actual net benefits for environmental, economic and social sustainability, potential trade-offs, and the rebound effects of implementing such technologies.

The outcomes of this study will be used in further research to map and analyse the value chain network, circular strategies and business models, and associated enabling DTs for different stakeholder groups in the BE research.

Supplementary Materials: The following are available online at https:/ /www.mdpi.com/article/10 $.3390 /$ su13116348/s1. Table S1: Literature overview at the intersection of DTs, CE and the BE. Table S2: References on the CDB framework. Figure S1: Workshop findings in full-size.

Author Contributions: Conceptualization, S.Ç., C.D.W., N.B.; methodology, S.Ç., C.D.W., N.B.; investigation, S.Ç.; workshops: S.Ç., C.D.W.; data curation, S.Ç.; literature review: S.Ç., C.D.W.; writing —original draft preparation, S.Ç.; writing—-ext preparation: S.Ç., C.D.W.; writing-review and editing, S.Ç., C.D.W., N.B.; visualization, S.Ç.; project administration, S.Ç. All authors have read and agreed to the published version of the manuscript.

Funding: S.Ç. received funding from the CHARM Project (Circular Housing Asset Renovation and Management-No More Downcycling) under INTERREG NWE grant number 760. N.B. was funded through the European Union's Horizon 2020's European research Council (ERC) funding scheme under grant agreement No 850159, project Circular X (www.circularx.eu accessed on 2 June 2021).

Institutional Review Board Statement: The study was conducted according to the guidelines of the Declaration of Helsinki and approved by the Human Research Ethics Committee of the Delft University of Technology.

Informed Consent Statement: Informed consent was obtained from all of the subjects involved in the study.

Acknowledgments: We would like to thank all of the experts who participated in the workshops for their valuable contribution to our study.

Conflicts of Interest: The authors declare no conflict of interest.

\section{Appendix A}

Table A1. The search strings used and the articles mapped from the literature review.

\begin{tabular}{|c|c|c|c|c|}
\hline Search Focus & Search Strings & $\begin{array}{c}\text { Number of } \\
\text { Search Results }\end{array}$ & $\begin{array}{c}\text { Number of } \\
\text { Relevant Articles }\end{array}$ & $\begin{array}{l}\text { Mapped onto the CDB } \\
\text { Framework }\end{array}$ \\
\hline $\begin{array}{l}\text { Additive/Robotic } \\
\text { Manufacturing }\end{array}$ & $\begin{array}{l}\text { "circular economy" AND ("3D printing" OR } \\
\text { "additive manufacturing" OR robotic* OR } \\
\text { "digital fabrication") AND (construction OR } \\
\text { building OR "built environment") }\end{array}$ & 24 & 8 & {$[52,111,122,126,131,204]$} \\
\hline $\begin{array}{l}\text { Artificial } \\
\text { Intelligence }\end{array}$ & $\begin{array}{l}\text { "circular economy" AND (ai OR "artificial } \\
\text { intelligence" OR "machine learning" OR } \\
\text { "deep learning") AND (construction OR } \\
\text { building OR "built environment") }\end{array}$ & 16 & 5 & {$[69,138,141,142,144]$} \\
\hline
\end{tabular}


Table A1. Cont.

\begin{tabular}{|c|c|c|c|c|}
\hline Search Focus & Search Strings & $\begin{array}{c}\text { Number of } \\
\text { Search Results }\end{array}$ & $\begin{array}{c}\text { Number of } \\
\text { Relevant Articles }\end{array}$ & $\begin{array}{l}\text { Mapped onto the CDB } \\
\text { Framework }\end{array}$ \\
\hline $\begin{array}{l}\text { Big Data, and } \\
\text { Analytics }\end{array}$ & $\begin{array}{c}\text { "circular economy" AND ("big data" OR } \\
\text { "big data analytics") AND (construction OR } \\
\text { building OR "built environment") }\end{array}$ & 9 & 0 & 0 \\
\hline $\begin{array}{l}\text { Blockchain } \\
\text { Technology }\end{array}$ & $\begin{array}{c}\text { "circular economy" AND (blockchain OR } \\
\text { "block chain") AND (construction OR } \\
\text { building OR "built environment") }\end{array}$ & 9 & 2 & {$[156,197]$} \\
\hline $\begin{array}{l}\text { Building } \\
\text { Information } \\
\text { Modelling }\end{array}$ & $\begin{array}{l}\text { "circular economy" AND (bim OR "building } \\
\text { information model }{ }^{* \prime} \text { ) AND (construction OR } \\
\text { building OR "built environment") }\end{array}$ & 45 & 26 & $\begin{array}{c}{[43,48,49,54,162,166,168,192} \\
194,195,197,205,206]\end{array}$ \\
\hline $\begin{array}{c}\text { Digital } \\
\text { Marketplaces }\end{array}$ & $\begin{array}{c}\text { "circular economy" AND (marketplace OR } \\
\text { "market place" OR “digital market" }{ }^{* \prime} \text { AND } \\
\text { (construction OR building OR “built } \\
\text { environment") }\end{array}$ & 8 & 4 & {$[181,207]$} \\
\hline Digital Platforms & $\begin{array}{c}\text { "circular economy" AND (platform OR } \\
\text { "digital platform" OR "online platform") } \\
\text { AND (construction OR building OR “built } \\
\text { environment") }\end{array}$ & 52 & 6 & {$[55,96,106,180,181]$} \\
\hline Digital Twins & $\begin{array}{c}\text { "circular economy" AND “DIGITAL TWIN" } \\
\text { AND (construction OR building OR "built } \\
\text { environment") }\end{array}$ & 3 & 2 & [208] \\
\hline $\begin{array}{l}\text { Geographical } \\
\text { Information System }\end{array}$ & $\begin{array}{c}\text { "circular economy" AND (gis OR } \\
\text { "Geograph* information system") AND } \\
\text { (construction OR building OR "built } \\
\text { environment") }\end{array}$ & 14 & 5 & {$[104,106,188,190]$} \\
\hline $\begin{array}{l}\text { Material Passports } \\
\text { and Databanks }\end{array}$ & $\begin{array}{c}\text { "circular economy" AND (passport OR } \\
\text { "material passport" OR "resource passport" } \\
\text { OR databank OR database) AND } \\
\text { (construction OR building OR "built } \\
\text { environment") }\end{array}$ & 60 & 11 & {$[50,96,180,191,194,195,209,210]$} \\
\hline $\begin{array}{l}\text { The Internet of } \\
\text { Things }\end{array}$ & $\begin{array}{l}\text { "circular economy" AND (iot OR "internet of } \\
\text { things" OR "rfid" OR "wireless sensor } \\
\text { networks") AND (construction OR building } \\
\text { OR "built environment") }\end{array}$ & 25 & 8 & {$[54,55,197,201,211-213]$} \\
\hline Total & & 265 & 77 & \\
\hline
\end{tabular}

\section{References}

1. United Nations Department of Economis and Social Affiars. 2018 Revision of World Urbanization Prospects. 2018. Available online: https:/ / www.un.org/development/desa/publications/2018-revision-of-world-urbanization-prospects.html (accessed on 8 April 2021).

2. UN-Habitat. SDG Indicator 11.1.1 Training Module: Adequate Housing and Slum Upgrading; United Nations Human Settlement Programme (UN-Habitat): Nairobi, Kenya, 2018.

3. Giljum, S.; Wieland, H.; Lutter, S.; Bruckner, M.; Wood, R.; Tukker, A.; Stadler, K. Identifying priority areas for European resource policies: A MRIO-based material footprint assessment. J. Econ. Struct. 2016, 5, 17. [CrossRef]

4. Herczeg, M.; McKinnon, D.; Milios, L.; Bakas, I.; Klaassens, E.; Svatikova, K.; Widerberg, O. Resource Efficiency in the Building Sector; DG Environment: Rotterdam, The Netherlands, 2014.

5. Eurostat. Waste Statistics. Available online: https:/ / ec.europa.eu/eurostat/statistics-explained/index.php/Waste_statistics\# Total_waste_generation (accessed on 13 April 2021).

6. Abergel, T.; Dulac, J.; Hamilton, I.; Jordan, M.; Pradeep, A. 2019 Global Status Report for Buildings and Construction-Towards a Zero-Emissions, Efficient and Resilient Buildings and Construction Sector. Available online: https://www.worldgbc.org/newsmedia/2019-global-status-report-buildings-and-construction (accessed on 10 March 2021).

7. European Commission. Construction Sector-A Global Player; Internal Market, Industry, Entrepreneurship and SMEs Directorate General Energy Directorate General Joint Research Centre (JRC): Brussels, Belgium, 2016.

8. Potting, J.; Kroeze, C. Cradle to cradle: Old wine or new spirits? Integr. Environ. Assess. Manag. Int. J. 2010, 6, 315-317. [CrossRef]

9. Boulding, K. The Economics of the Coming Spaceship Earth; Johns Hopkins University Press: New York, NY, USA, 1966.

10. Sears, P.B. The Closing Circle: Nature, Man \& Technology. Nat. Resour. J. 1973, 13, 549.

11. McDonough, W.; Braungart, M. Cradle to Cradle: Remaking the Way We Make Things; North Point Press: New York, NY, USA, 2010.

12. Benyus, J.M. Biomimicry: Innovation Inspired by Nature; Harper Perennial: New York, NY, USA, 2002. 
13. Stahel, W. The utilization-focused service economy-Resource efficiency and product-life extension. In The Greening of Industrial Ecosystems; Richards, D.J., Allenby, B.E., Eds.; National Academies Press: Washington, DC, USA, 1994.

14. Bocken, N.M.P.; Olivetti, E.A.; Cullen, J.M.; Potting, J.; Lifset, R. Taking the Circularity to the Next Level: A Special Issue on the Circular Economy. J. Ind. Ecol. 2017, 21, 476-482. [CrossRef]

15. Kirchherr, J.; Reike, D.; Hekkert, M. Conceptualizing the circular economy: An analysis of 114 definitions. Resour. Conserv. Recycl. 2017, 127, 221-232. [CrossRef]

16. Bocken, N.; Stahel, W.; Dobrauz, G.N.; Koumbarakis, A.; Obst, M.; Matzdorf, P. Circularity as the New Normal-Future Fitting Swiss Businesses; PwC Switzerland: Zurich, Switzerland; WWF Switzerland: Zurich, Switzerland, 2021.

17. Bocken, N.M.P.; de Pauw, I.; Bakker, C.; van der Grinten, B. Product design and business model strategies for a circular economy. J. Ind. Prod. Eng. 2016, 33, 308-320. [CrossRef]

18. Konietzko, J.; Bocken, N.; Hultink, E.J. A Tool to Analyze, Ideate and Develop Circular Innovation Ecosystems. Sustainability 2020, 12, 417. [CrossRef]

19. World Commission on Environment and Development. Our Common Future; United Nations: Oslo, Norway, 1987.

20. Ellen MacArthur Foundation. Circularity in the Built Environment: Case Studies. A Compilation of Case Studies from the CE100. 2016. Available online: www.ellenmacarthurfoundation.org/assets/downloads/Built-Env-Co.Project.pdf (accessed on 8 April 2021).

21. ARUP. Circular Economy in the Built Environment. Available online: https://www.arup.com/perspectives/publications/ research/section/circular-economy-in-the-built-environment (accessed on 10 March 2021).

22. Iacovidou, E.; Purnell, P. Mining the physical infrastructure: Opportunities, barriers and interventions in promoting structural components reuse. Sci. Total Environ. 2016, 557-558, 791-807. [CrossRef]

23. BAMB. Available online: https://www.bamb2020.eu/ (accessed on 11 April 2021).

24. Rotor. Available online: http://rotordb.org/en (accessed on 11 April 2021).

25. Cycle up. Available online: https://www.cycle-up.fr/ (accessed on 11 April 2021).

26. Baubüro In Situ. Available online: https:/ / www.insitu.ch/ (accessed on 11 April 2021).

27. De Wolf, C.; Hoxha, E.; Fivet, C. Comparison of environmental assessment methods when reusing building components: A case study. Sustain. Cities Soc. 2020, 61, 102322. [CrossRef]

28. European Commission. Europe's Digital Decade: Commission Sets the Course Towards a Digitally Empowered Europe by 2030. 2021. Available online: https:/ / ec.europa.eu/commission/presscorner/detail/en/IP_21_983 (accessed on 11 April 2021).

29. European Commission. EU Circular Economy Action Plan. Available online: https://ec.europa.eu/environment/circulareconomy/index_en.htm (accessed on 11 April 2020).

30. Bressanelli, G.; Adrodegar, F.; Perona, M.; Saccani, N. Exploring How Usage-Focused Business Models Enable Circular Economy through Digital Technologies. Sustainability 2018, 10, 639. [CrossRef]

31. Lopes de Sousa Jabbour, A.B.; Jabbour, C.J.C.; Godinho Filho, M.; Roubaud, D. Industry 4.0 and the circular economy: A proposed research agenda and original roadmap for sustainable operations. Ann. Oper. Res. 2018, 270, 273-286. [CrossRef]

32. Okorie, O.; Salonitis, K.; Charnley, F.; Moreno, M.; Turner, C.; Tiwari, A. Digitisation and the Circular Economy: A Review of Current Research and Future Trends. Energies 2018, 11, 3009. [CrossRef]

33. Pagoropoulos, A.; Pigosso, D.C.A.; McAloone, T.C. The Emergent Role of Digital Technologies in the Circular Economy: A Review. Procedia CIRP 2017, 64, 19-24. [CrossRef]

34. Rosa, P.; Sassanelli, C.; Urbinati, A.; Chiaroni, D.; Terzi, S. Assessing relations between Circular Economy and Industry 4.0: A systematic literature review. Int. J. Prod. Res. 2019, 58, 1662-1687. [CrossRef]

35. Ingemarsdotter, E.; Jamsin, E.; Kortuem, G.; Balkenende, R. Circular Strategies Enabled by the Internet of Things-A Framework and Analysis of Current Practice. Sustainability 2019, 11, 5689. [CrossRef]

36. Chan, P.W.; De Wolf, C.; Koutamanis, A. The Digital Potential in Creating a Circular Construction Economy; Technische Universiteit Delft: Delft, The Netherlands, 2020.

37. ARUP. Digital Twin: Towards a Meaningful Framework. Available online: https://www.arup.com/perspectives/publications/ research/section/digital-twin-towards-a-meaningful-framework (accessed on 10 March 2021).

38. Hunhevicz, J.J.; Hall, D.M. Do you need a blockchain in construction? Use case categories and decision framework for DLT design options. Adv. Eng. Inform. 2020, 45, 101094. [CrossRef]

39. Tang, S.; Shelden, D.R.; Eastman, C.M.; Pishdad-Bozorgi, P.; Gao, X. A review of building information modeling (BIM) and the internet of things (IoT) devices integration: Present status and future trends. Autom. Constr. 2019, 101, 127-139. [CrossRef]

40. Dave, B.; Kubler, S.; Främling, K.; Koskela, L. Opportunities for enhanced lean construction management using Internet of Things standards. Autom. Constr. 2016, 61, 86-97. [CrossRef]

41. National Centre of Competence in Research. Digital Fabrication. Available online: https://dfab.ch/\# (accessed on 8 April 2021).

42. Wang, H.; Pan, Y.; Luo, X. Integration of BIM and GIS in sustainable built environment: A review and bibliometric analysis. Autom. Constr. 2019, 103, 41-52. [CrossRef]

43. Akinade, O.O.; Oyedele, L.O. Integrating construction supply chains within a circular economy: An ANFIS-based waste analytics system (A-WAS). J. Clean. Prod. 2019, 229, 863-873. [CrossRef]

44. Pomponi, F.; Moncaster, A. Circular economy for the built environment: A research framework. J. Clean. Prod. 2017, 143, 710-718. [CrossRef] 
45. Kovacic, I.; Honic, M.; Sreckovic, M. Digital Platform for Circular Economy in AEC Industry. Eng. Proj. Organ. J. 2020, 9. Available online: https:/ / publik.tuwien.ac.at/files/publik_290949.pdf (accessed on 6 April 2021). [CrossRef]

46. Darko, A.; Chan, A.P.C.; Adabre, M.A.; Edwards, D.J.; Hosseini, M.R.; Ameyaw, E.E. Artificial intelligence in the AEC industry: Scientometric analysis and visualization of research activities. Autom. Constr. 2020, 112, 103081. [CrossRef]

47. Madaster. Madaster-The Materials Cadastre. Available online: https://madaster.com/ (accessed on 30 March 2021).

48. Akanbi, L.A.; Oyedele, L.O.; Akinade, O.O.; Ajayi, A.O.; Davila Delgado, M.; Bilal, M.; Bello, S.A. Salvaging building materials in a circular economy: A BIM-based whole-life performance estimator. Resour. Conserv. Recycl. 2018, 129, 175-186. [CrossRef]

49. Akanbi, L.A.; Oyedele, L.O.; Omoteso, K.; Bilal, M.; Akinade, O.O.; Ajayi, A.O.; Davila Delgado, J.M.; Owolabi, H.A. Disassembly and deconstruction analytics system (D-DAS) for construction in a circular economy. J. Clean. Prod. 2019, 223, 386-396. [CrossRef]

50. Honic, M.; Kovacic, I.; Rechberger, H. Improving the recycling potential of buildings through Material Passports (MP): An Austrian case study. J. Clean. Prod. 2019, 217, 787-797. [CrossRef]

51. Honic, M.; Kovacic, I.; Sibenik, G.; Rechberger, H. Data- and stakeholder management framework for the implementation of BIM-based Material Passports. J. Build. Eng. 2019, 23, 341-350. [CrossRef]

52. Álvarez-Fernández, M.-I.; Prendes-Gero, M.-B.; González-Nicieza, C.; Guerrero-Miguel, D.-J.; Martínez-Martínez, J.E. Optimum Mix Design for 3D Concrete Printing Using Mining Tailings: A Case Study in Spain. Sustainability 2021, 13, 1568. [CrossRef]

53. Li, C.Z.; Chen, Z.; Xue, F.; Kong, X.T.R.; Xiao, B.; Lai, X.; Zhao, Y. A blockchain- and IoT-based smart product-service system for the sustainability of prefabricated housing construction. J. Clean. Prod. 2021, 286, 125391. [CrossRef]

54. Turner, C.; Oyekan, J.; Stergioulas, L.K. Distributed Manufacturing: A New Digital Framework for Sustainable Modular Construction. Sustainability 2021, 13, 1515. [CrossRef]

55. Xing, K.; Kim, K.P.; Ness, D. Cloud-BIM Enabled Cyber-Physical Data and Service Platforms for Building Component Reuse. Sustainability 2020, 12, 329. [CrossRef]

56. Snyder, H. Literature review as a research methodology: An overview and guidelines. J. Bus. Res. 2019, 104, 333-339. [CrossRef]

57. Google. Available online: https:/ / www.google.com/ (accessed on 6 April 2021).

58. Ecosia. Available online: https://www.ecosia.org/ (accessed on 6 April 2021).

59. Durmisevic, E. Circular Economy in Construction, Design Strategies for Reversible Buildings; BAMB Consortium, Ed.; BAMB (Buildings as Material Banks): Brussels, Belgium, 2019.

60. Eberhardt, L.C.M.; Birkved, M.; Birgisdottir, H. Building design and construction strategies for a circular economy. Archit. Eng. Des. Manag. 2020, 1-21. [CrossRef]

61. Leising, E.; Quist, J.; Bocken, N. Circular Economy in the building sector: Three cases and a collaboration tool. J. Clean. Prod. 2018, 176, 976-989. [CrossRef]

62. NEN. NEN-EN 15978:2011-Sustainability of Construction Works. Assessment of Environmental Performance of Buildings. Calculation Method; British Standards Institution: London, UK, 2011.

63. Benachio, G.L.F.; do Carmo Duarte Freitas, M.; Tavares, S.F. Circular economy in the construction industry: A systematic literature review. J. Clean. Prod. 2020, 260, 121046. [CrossRef]

64. Mannan, M.; Al-Ghamdi, S.G. Environmental impact of water-use in buildings: Latest developments from a life-cycle assessment perspective. J. Environ. Manag. 2020, 261, 110198. [CrossRef]

65. Tahir, S.; Steele, K.; Shouler, M.; Steichen, T.; Penning, P.; Martin, N.; Ellen MacArthur Foundation. Water and Circular Economy: A White Paper; ARUP: London, UK; Antea Group: St. Paul, MN, USA; Ellen MacArthur Foundation: Cowes, UK, 2018.

66. Pimentel-Rodrigues, C.; Siva-Afonso, A. Reuse of resources in the use phase of buildings. Solutions for water. IOP Conf. Ser. Earth Environ. Sci. 2019, 225, 012050. [CrossRef]

67. Cabeza, L.F.; Rincón, L.; Vilariño, V.; Pérez, G.; Castell, A. Life cycle assessment (LCA) and life cycle energy analysis (LCEA) of buildings and the building sector: A review. Renew. Sustain. Energy Rev. 2014, 29, 394-416. [CrossRef]

68. Amenta, L.; van Timmeren, A. Beyond Wastescapes: Towards Circular Landscapes. Addressing the Spatial Dimension of Circularity through the Regeneration of Wastescapes. Sustainability 2018, 10, 4740. [CrossRef]

69. Gan, V.J.L.; Lo, I.M.C.; Ma, J.; Tse, K.T.; Cheng, J.C.P.; Chan, C.M. Simulation optimisation towards energy efficient green buildings: Current status and future trends. J. Clean. Prod. 2020, 254, 120012. [CrossRef]

70. Hossain, M.U.; Ng, S.T.; Antwi-Afari, P.; Amor, B. Circular economy and the construction industry: Existing trends, challenges and prospective framework for sustainable construction. Renew. Sustain. Energy Rev. 2020, 130, 109948. [CrossRef]

71. Munaro, M.R.; Tavares, S.F.; Bragança, L. Towards circular and more sustainable buildings: A systematic literature review on the circular economy in the built environment. J. Clean. Prod. 2020, 260, 121134. [CrossRef]

72. Van Stijn, A.; Gruis, V. Towards a circular built environment-An integral design tool for circular building components. Smart Sustain. Built Environ. 2019, 9, 2046-6099. [CrossRef]

73. Minunno, R.; O'Grady, T.; Morrison, G.; Gruner, R.; Colling, M. Strategies for Applying the Circular Economy to Prefabricated Buildings. Buildings 2018, 8, 125. [CrossRef]

74. Kedir, F.; Hall, D.M. Resource efficiency in industrialized housing construction-A systematic review of current performance and future opportunities. J. Clean. Prod. 2021, 286, 125443. [CrossRef]

75. Geldermans, R.J. Design for Change and Circularity-Accommodating Circular Material \& Product Flows in Construction. Energy Procedia 2016, 96, 301-311. [CrossRef] 
76. Kyrö, R. Share, Preserve, Adapt, Rethink-A focused framework for circular economy. In Proceedings of the BEYOND 2020World Sustainable Built Environment Online Conference, Göteborg, Sweden, 2-4 November 2020.

77. Morseletto, P. Restorative and regenerative: Exploring the concepts in the circular economy. J. Ind. Ecol. 2020, $24,763-773$. [CrossRef]

78. Attia, S. Regenerative and Positive Impact Architecture—Learning from Case Studies; Springer: Liège, Belgium, 2018.

79. Lyle, J.T. Regenerative Design for Sustainable Development; John Wiley \& Sons: Hoboken, NJ, USA, 1996.

80. Mang, P.; Reed, B. Designing from place: A regenerative framework and methodology. Build. Res. Inf. 2012, 40, 23-38. [CrossRef]

81. Reed, B. Shifting from 'sustainability' to regeneration. Build. Res. Inf. 2007, 35, 674-680. [CrossRef]

82. Craft, W.; Ding, L.; Prasad, D.; Partridge, L.; Else, D. Development of a Regenerative Design Model for Building Retrofits. Procedia Eng. 2017, 180, 658-668. [CrossRef]

83. Kubbinga, B.; Bamberger, M.; van Noort, E.; van den Reek, D.; Blok, M.; Roemers, G.; Hoek, J.; Faes, K. A Framework for Circular Buildings-Indicators for Possible Inclusion in BREEAM; Circle Economy: Amsterdam, The Netherlands; Metabolic: Amsterdam, The Netherlands; Dutch Green Building Council: Den Haag, The Netherlands; SGS: Geneva, Switzerland; REDEVCO Foundation: Amsterdam, The Netherlands, 2018.

84. Thomaier, S.; Specht, K.; Henckel, D.; Dierich, A.; Siebert, R.; Freisinger, U.B.; Sawicka, M. Farming in and on urban buildings: Present practice and specific novelties of Zero-Acreage Farming (ZFarming). Renew. Agric. Food Syst. 2014, 30, 43-54. [CrossRef]

85. Calheiros, C.S.C.; Stefanakis, A.I. Green Roofs Towards Circular and Resilient Cities. Circ. Econ. Sustain. 2021. [CrossRef]

86. RESILIO. Blauw-Groene Daken. Available online: https://resilio.amsterdam/en/ (accessed on 24 March 2021).

87. Strunge, J.W. Enabling regenerative building design through biohacking. In Proceedings of the BEYOND 2020-World Sustainable Built Environment Online Conference, Göteborg, Sweden, 2-4 November 2020.

88. Biohm. Mycelium Insulation. Available online: https:/ /www.biohm.co.uk/mycelium (accessed on 24 March 2021).

89. Mengelkamp, E.; Notheisen, B.; Beer, C.; Dauer, D.; Weinhardt, C. A blockchain-based smart grid: Towards sustainable local energy markets. Comput. Sci. Res. Dev. 2017, 33, 207-214. [CrossRef]

90. Lo 3 Energy. Pando. Available online: https:/ / lo3energy.com/pando/ (accessed on 15 March 2021).

91. Skillington, K.; Crawford, R.H. Design for Dematerialisation-Examining an approach for reducing the life cycle energy requiremen. In Proceedings of the BEYOND 2020—World Sustainable Built Environment Online Conference, Göteborg, Sweden, 2-4 November 2020.

92. Block, P.; Schlueter, A.; Veenendaal, D.; Bakker, J.; Begle, M.; Hischier, I.; Hofer, J.; Jayathissa, P.; Maxwell, I.; Echenagucia, T.M.; et al. NEST HiLo: Investigating lightweight construction and adaptive energy systems. J. Build. Eng. 2017, 12, 332-341. [CrossRef]

93. Konis, K.; Gamas, A.; Kensek, K. Passive performance and building form: An optimization framework for early-stage design support. Sol. Energy 2016, 125, 161-179. [CrossRef]

94. Enervalis. Rennovates Project. Available online: https://www.enervalis.com/rennovates-project/ (accessed on 24 March 2021).

95. Wood, B. Maintenance Integrated Design and Manufacture of Buildings: Toward a Sustainable Model. J. Archit. Eng. 2012, 18, 192-197. [CrossRef]

96. Heisel, F.; Rau-Oberhuber, S. Calculation and evaluation of circularity indicators for the built environment using the case studies of UMAR and Madaster. J. Clean. Prod. 2020, 243, 118482. [CrossRef]

97. Olivadese, R.; Remøy, H.; Berizzi, C.; Hobma, F. Reuse into housing: Italian and Dutch regulatory effects. Prop. Manag. 2017, 35, 165-180. [CrossRef]

98. Foster, G. Circular economy strategies for adaptive reuse of cultural heritage buildings to reduce environmental impacts. Resour. Conserv. Recycl. 2020, 152, 104507. [CrossRef]

99. ARUP. From Principles to Practices: Realising the Value of the Circular Economy in Real Estate. Available online: https: //www.arup.com/perspectives/publications/research/section/realising-the-value-of-circular-economy-in-real-estate (accessed on 10 January 2021).

100. Workfrom. Available online: https:/ / workfrom.co/ (accessed on 24 March 2021).

101. Fargnoli, M.; Lleshaj, A.; Lombardi, M.; Sciarretta, N.; Di Gravio, G. A BIM-based PSS Approach for the Management of Maintenance Operations of Building Equipment. Buildings 2019, 9, 139. [CrossRef]

102. Philips Lighting. RAU Amsterdam. Available online: https://www.lighting.philips.nl/inspiratie/projecten/kantoor/ architectenbureau-rau (accessed on 25 March 2021).

103. Ghisellini, P.; Ripa, M.; Ulgiati, S. Exploring environmental and economic costs and benefits of a circular economy approach to the construction and demolition sector. A literature review. J. Clean. Prod. 2018, 178, 618-643. [CrossRef]

104. Oezdemir, O.; Krause, K.; Hafner, A. Creating a Resource Cadaster-A Case Study of a District in the Rhine-Ruhr Metropolitan Area. Buildings 2017, 7, 45. [CrossRef]

105. Metabolic. Urban Mining and Circular Construction-What, Why and How it Works. Available online: https:/ / www.metabolic $\mathrm{nl} /$ news/urban-mining-and-circular-construction/ (accessed on 26 April 2021).

106. Yu, Y.; Yazan, D.M.; Bhochhibhoya, S.; Volker, L. Towards Circular Economy through Industrial Symbiosis in the Dutch construction industry: A case of recycled concrete aggregates. J. Clean. Prod. 2021, 293, 126083. [CrossRef]

107. Brown, P.; Bocken, N.; Balkenende, R. Why Do Companies Pursue Collaborative Circular Oriented Innovation? Sustainability 2019, 11, 635. [CrossRef] 
108. Pianoo. Buyer Groups for Sustainability. Available online: https://www.pianoo.nl/en/sustainable-public-procurement/buyergroups-sustainability (accessed on 13 April 2021).

109. Deloitte. The Edge of Tomorrow. Available online: https://www2.deloitte.com/ru/en/pages/about-deloitte/articles/gx-theedge-of-tomorrow.html (accessed on 16 March 2021).

110. Gibson, I.; Rosen, D.; Stucker, B. Introduction and Basic Principles. In Additive Manufacturing Technologies. 3D Printing, Rapid Prototyping, and Direct Digital Manufacturing; Gibson, I., Rosen, D., Stucker, B., Eds.; Springer: New York, NY, USA, 2015; pp. 1-18. [CrossRef]

111. Albar, A.; Swash, M.R.; Ghaffar, S. The Design and Development of an Extrusion System for 3D Printing Cementitious Materials. In Proceedings of the 2019 3rd International Symposium on Multidisciplinary Studies and Innovative Technologies (ISMSIT), Ankara, Turkey, 11-13 October 2019.

112. Paolini, A.; Kollmannsberger, S.; Rank, E. Additive manufacturing in construction: A review on processes, applications, and digital planning methods. Addit. Manuf. 2019, 30, 100894. [CrossRef]

113. Devadass, P.; Heimig, T.; Stumm, S.; Kerber, E.; Cokcan, S.B. Robotic Constraints Informed Design Process. In Proceedings of the 39th Annual Conference of the Association for Computer Aided Design in Architecture (ACADIA), Austin, TX, USA, 24-26 October 2019; pp. 130-139.

114. Huang, Y.; Garrett, C.R.; Mueller, C.T. Automated sequence and motion planning for robotic spatial extrusion of 3D trusses. Constr. Robot. 2018, 2, 15-39. [CrossRef]

115. Ercan Jenny, S.; Lloret-Fritschi, E.; Gramazio, F.; Kohler, M. Crafting plaster through continuous mobile robotic fabrication on-site. Constr. Robot. 2020, 4, 261-271. [CrossRef]

116. De Soto, B.; Agustí-Juan, I.; Hunhevicz, J.; Joss, S.; Graser, K.; Habert, G.; Adey, B.T. Productivity of digital fabrication in construction: Cost and time analysis of a robotically built wall. Autom. Constr. 2018, 92, 297-311. [CrossRef]

117. Robeller, C.; Mayencourt, P.; Weinand, Y. Snap-fit Joints-CNC fabricated, Integrated Mechanical Attachment for Structural Wood Panels. In Proceedings of the ACADIA 2014 Design Agency: Proceedings of the 34th Annual Conference of the Association for Computer Aided Design in Architecture, Los Angeles, CA, USA, 23-25 October 2014; pp. 189-198.

118. Rippmann, M.; Liew, A.; Van Mele, T.; Block, P. Design, fabrication and testing of discrete 3D sand-printed floor prototypes. Mater. Today Commun. 2018, 15, 254-259. [CrossRef]

119. De Schutter, G.; Lesage, K.; Mechtcherine, V.; Nerella, V.N.; Habert, G.; Agusti-Juan, I. Vision of 3D printing with concreteTechnical, economic and environmental potentials. Cem. Concr. Res. 2018, 112, 25-36. [CrossRef]

120. Oberti, I.; Plantamura, F. Is 3D printed house sustainable? In Proceedings of the International Conference CISBAT 2015 Future Buildings and Districts Sustainability from Nano to Urban Scale, Lausanne, Switzerland, 9-11 September 2011; pp. 173-178.

121. Hager, I.; Golonka, A.; Putanowicz, R. 3D Printing of Buildings and Building Components as the Future of Sustainable Construction? Procedia Eng. 2016, 151, 292-299. [CrossRef]

122. Wang, J. Digital Architextiles-Nonwoven textile thermoforming in robotic fabrication. In Proceedings of the Anthropocene, Design in the Age of Humans-25th CAADRIA Conference Bangkok, Thailand, 7-10 April 2019; pp. 45-54.

123. Agustí-Juan, I.; Habert, G. Environmental design guidelines for digital fabrication. J. Clean. Prod. 2017, 142, 2780-2791. [CrossRef]

124. He, Y.; Zhang, Y.; Zhang, C.; Zhou, H. Energy-saving potential of 3D printed concrete building with integrated living wall. Energy Build. 2020, 222, 110110. [CrossRef]

125. MX3D. MX3D Bridge. Available online: https://mx3d.com/projects/mx3d-bridge/ (accessed on 14 April 2021).

126. Baiani, S.; Altamura, P. Waste materials superuse and upcycling in architecture: Design and experimentation. Techne 2018, 16, 142-151. [CrossRef]

127. Bier, H.H.; Nazzarri, G. Towards Circular Economy in Architecture by Means of Data-driven Design-to-Robotic-Production. In Proceedings of the 37th International Symposium on Automation and Robotics in Construction, Kitakyushu, Japan, 26-30 October 2020.

128. Brütting, J.; Senatore, G.; Fivet, C. Design and fabrication of a reusable kit of parts for diverse structures. Autom. Constr. 2021, 125, 103614. [CrossRef]

129. Kunic, A.; Naboni, R.; Kramberger, A.; Schlette, C. Design and assembly automation of the Robotic Reversible Timber Beam. Autom. Constr. 2021, 123, 103531. [CrossRef]

130. Kuzmenko, K.; Roux, C.; Feraille, A.; Baverel, O. Assessing environmental impact of digital fabrication and reuse of constructive systems. Structures 2020, 31, 1300-1310. [CrossRef]

131. Robertson, O.; Høgdal, F.; Mckay, L.; Lenau, T. Fungal Future: A review of mycelium biocomposites as an ecological alternative insulation material. In Proceedings of the NordDesign 2020, Copenhagen, Denmark, 12-14 August 2020.

132. Smith, R.S.H.; Bader, C.; Sharma, S.; Kolb, D.; Tang, T.C.; Hosny, A.; Moser, F.; Weaver, J.C.; Voigt, C.A.; Oxman, N. Hybrid Living Materials: Digital Design and Fabrication of 3D Multimaterial Structures with Programmable Biohybrid Surfaces. Adv. Funct. Mater. 2019, 30, 1907401. [CrossRef]

133. Stuart, R.; Norvig, P. Artificial Intelligence: A Modern Approach, 2nd ed.; Pearson Education Inc.: Upper Saddle River, NJ, USA, 2003.

134. IBM. Artificial Intelligence (AI). 2020. Available online: https://www.ibm.com/cloud/learn/what-is-artificial-intelligence (accessed on 19 March 2021). 
135. IBM. AI vs. Machine Learning vs. Deep Learning vs. Neural Networks: What's the Difference? 2020. Available online: https://www.ibm.com/cloud/blog/ai-vs-machine-learning-vs-deep-learning-vs-neural-networks (accessed on 19 March 2021).

136. Ellen MacArthur Foundation; Google. Artificial Intelligence and the Circular Economy-AI as a Tool to Accelerate the Transition. Available online: https:/ / www.ellenmacarthurfoundation.org/publications/artificial-intelligence-and-the-circular-economy (accessed on 19 March 2019).

137. Arcadis. Artificial Intelligence in the AAEC Indsutry-A Code of Practice. Available online: https://www.arcadis.com/en/ knowledge-hub/blog/global/susanne-knorr/2020/the-future-of-architecture,-engineering,-and-construction-is-digital-andintelligent (accessed on 2 June 2021).

138. Płoszaj-Mazurek, M.; Ryńska, E.; Grochulska-Salak, M. Methods to Optimize Carbon Footprint of Buildings in Regenerative Architectural Design with the Use of Machine Learning, Convolutional Neural Network, and Parametric Design. Energies 2020, 13, 5289. [CrossRef]

139. Mehmood, M.U.; Chun, D.; Zeeshan; Han, H.; Jeon, G.; Chen, K. A review of the applications of artificial intelligence and big data to buildings for energy-efficiency and a comfortable indoor living environment. Energy Build. 2019, 202. [CrossRef]

140. Facade Service Applicatie. Platform voor Digitale Innovatie in de Vasgoedmarkt. Available online: https:/ / facadeserviceapplicatie. $\mathrm{nl} /$ (accessed on 29 March 2021).

141. Akanbi, L.A.; Oyedele, A.O.; Oyedele, L.O.; Salami, R.O. Deep learning model for Demolition Waste Prediction in a circular economy. J. Clean. Prod. 2020, 274, 122843. [CrossRef]

142. Rakhshan, K.; Morel, J.-C.; Daneshkhah, A. A probabilistic predictive model for assessing the economic reusability of load-bearing building components: Developing a Circular Economy framework. Sustain. Prod. Consum. 2021, 27, 630-642. [CrossRef]

143. Davis, P.; Aziz, F.; Newaz, M.T.; Sher, W.; Simon, L. The classification of construction waste material using a deep convolutional neural network. Autom. Constr. 2021, 122, 103481. [CrossRef]

144. Lau Hiu Hoong, J.D.; Lux, J.; Mahieux, P.-Y.; Turcry, P.; Aït-Mokhtar, A. Determination of the composition of recycled aggregates using a deep learning-based image analysis. Autom. Constr. 2020, 116, 103204. [CrossRef]

145. McKinsey Global Institute. Big Data: The Next Frontier for Innovation, Competition, and Productivity. Available online: https: //www.mckinsey.com/business-functions/mckinsey-digital/our-insights/big-data-the-next-frontier-for-innovation (accessed on 2 June 2021).

146. Gandomi, A.; Haider, M. Beyond the hype: Big data concepts, methods, and analytics. Int. J. Inf. Manag. 2015, 35, 137-144. [CrossRef]

147. Yin, S.; Kaynak, O. Big Data for Modern Industry: Challenges and Trends (Point of View). Proc. IEEE 2015, 103, 143-146. [CrossRef]

148. Bilal, M.; Oyedele, L.O.; Qadir, J.; Munir, K.; Ajayi, S.O.; Akinade, O.O.; Owolabi, H.A.; Alaka, H.A.; Pasha, M. Big Data in the construction industry: A review of present status, opportunities, and future trends. Adv. Eng. Inform. 2016, 30, 500-521. [CrossRef]

149. Fan, C.; Xiao, F. Mining big building operational data for improving building energy efficiency: A case study. Build. Serv. Eng. Res. Technol. 2017, 39, 117-128. [CrossRef]

150. Panfilov, P.; Katona, A. Building Predictive Maintenance Framework for Smart Environment Application Systems. In Proceedings of the 29th International DAAAM Symposium “Intelligent Manufacturing \& Automation", Zadar, Croatia, 24-27 October 2018; pp. 460-470. [CrossRef]

151. Nobre, G.C.; Tavares, E. Scientific literature analysis on big data and internet of things applications on circular economy: A bibliometric study. Scientometrics 2017, 111, 463-492. [CrossRef]

152. Nakamoto, S. Bitcoin: A Peer-to-Peer Electronic Cash System. Available online: https://bitcoin.org/en/bitcoin-paper (accessed on 14 March 2021).

153. Arun, J.S.; Cuomo, J.; Gaur, N. Blockchain for Business; Addison-Wesley Professional: Boston, MA, USA, 2019.

154. Swan, M. Blockchain: Blueprint for a New Economy; McGovern, T., Ed.; O’Reilly Media, Inc.: Sebastopol, CA, USA, 2015.

155. Böckel, A.; Nuzum, A.-K.; Weissbrod, I. Blockchain for the Circular Economy: Analysis of the Research-Practice Gap. Sustain. Prod. Consum. 2021, 25, 525-539. [CrossRef]

156. Shojaei, A. Exploring Applications of Blockchain Technology in the Construction Industry. In Proceedings of the 10th International Structural Engineering and Construction Conference, Chicago, IL, USA, 20-25 May 2019.

157. Circularise. Available online: https:/ / www.circularise.com/ (accessed on 15 March 2021).

158. Licht, J.; de Jong, T.; Oudshoorn, K.; Pasotti, P. Circularise-White Paper. Available online: https://www.circularise.com/ whitepaper (accessed on 15 March 2021).

159. ARUP. Blockchain and the Built Environment. Available online: https://www.arup.com/perspectives/publications/research/ section/blockchain-and-the-built-environment (accessed on 1 March 2021).

160. Tata Steel. Available online: https: / / www.tatasteel.com/ (accessed on 15 March 2021).

161. Penzes, B. Blockchain Technology in the Construction Industry_Digital Transformation for High Productivity; Institution of Civil Engineers: London, UK, 2018.

162. Charef, R.; Emmitt, S. Uses of building information modelling for overcoming barriers to a circular economy. J. Clean. Prod. 2021, 285, 124854. [CrossRef]

163. Wong, K.D.; Fan, Q. Building information modelling (BIM) for sustainable building design. Facilities 2013, 31, 138-157. [CrossRef] 
164. Habibi, S. The promise of BIM for improving building performance. Energy Build. 2017, 153, 525-548. [CrossRef]

165. Xue, K.; Hossain, M.U.; Liu, M.; Ma, M.; Zhang, Y.; Hu, M.; Chen, X.; Cao, G. BIM Integrated LCA for Promoting Circular Economy towards Sustainable Construction: An Analytical Review. Sustainability 2021, 13, 1310. [CrossRef]

166. Aguiar, A.; Vonk, R.; Kamp, F. BIM and Circular Design. IOP Conf. Ser. Earth Environ. Sci. 2019, 225, 012068. [CrossRef]

167. Gao, X.; Pishdad-Bozorgi, P. BIM-enabled facilities operation and maintenance: A review. Adv. Eng. Inform. 2019, 39, $227-247$. [CrossRef]

168. Davila Delgado, J.M.; Oyedele, L.O. BIM data model requirements for asset monitoring and the circular economy. J. Eng. Des. Technol. 2020, 18, 1269-1285. [CrossRef]

169. Chen, J.; Bulbul, T.; Taylor, J.E.; Olgun, G. A Case Study of Embedding Real-time Infrastructure Sensor Data to BIM. In Proceedings of the Construction Research Congress 2014, Atlanta, GA, USA, 19-21 May 2014.

170. Van den Berg, M.; Voordijk, H.; Adriaanse, A. BIM uses for deconstruction: An activity-theoretical perspective on reorganising end-of-life practices. Constr. Manag. Econ. 2021, 39, 323-339. [CrossRef]

171. Chan, P.W. Construction in the platform society-New directions for construction management research. In Proceedings of the 36th Annual Conference 2020 (ARCOM 2020), Leeds, UK, 7-8 September 2020; pp. 396-405.

172. De Reuver, M.; Sørensen, C.; Basole, R.C. The Digital Platform: A Research Agenda. J. Inf. Technol. 2018, 33, 124-135. [CrossRef]

173. Asadullah, A.; Faik, I.; Kankanhalli, A. Digital Platforms: A Review and Future Directions. In Proceedings of the Pacific Asia Conference on Information Systems (PACIS), Yokohama, Japan, 26-30 June 2018.

174. Konietzko, J.; Bocken, N.; Hultink, E.J. Online Platforms and the Circular Economy. In Innovation for Sustainability; Bocken, N., Ritala, P., Albareda, L., Verburg, R., Eds.; Palgrave Macmillan: Cham, Switzerland, 2019; pp. 435-450. [CrossRef]

175. Ranjbari, M.; Morales-Alonso, G.; Carrasco-Gallego, R. Conceptualizing the Sharing Economy through Presenting a Comprehensive Framework. Sustainability 2018, 10, 2336. [CrossRef]

176. City of Amsterdam. Vacant Space Finding. Available online: https://maps.amsterdam.nl/stadsloods/?LANG=en (accessed on 1 April 2021).

177. EquipmentShare. Available online: https:/ / www.equipmentshare.com/ (accessed on 1 April 2021).

178. Excess Materials Exchange. The Most Valuable Match. Available online: https://excessmaterialsexchange.com/en_us/ (accessed on 1 April 2021).

179. Enviromate. Enviromate. Available online: https://www.enviromate.co.uk/ (accessed on 1 April 2021).

180. Oberti, I.; Paoletti, I. Da.Ma.Tra: Material Traceability Database. In Digital Transformation of the Design, Construction and Management Processes of the Built Environment; Dianotti, B., Gianinetto, M., Della Torre, S., Eds.; Springer: Cham, Switzerland, 2020; pp. 85-93. [CrossRef]

181. Luciano, A.; Cutaia, L.; Cioffi, F.; Sinibaldi, C. Demolition and construction recycling unified management: The DECORUM platform for improvement of resource efficiency in the construction sector. Environ. Sci. Pollut. Res. Int. 2020, 28, 24558-25469. [CrossRef] [PubMed]

182. Khajavi, S.H.; Motlagh, N.H.; Jaribion, A.; Werner, L.C.; Holmstrom, J. Digital Twin: Vision, Benefits, Boundaries, and Creation for Buildings. IEEE Access 2019, 7, 147406-147419. [CrossRef]

183. Tao, F.; Cheng, J.; Qi, Q.; Zhang, M.; Zhang, H.; Sui, F. Digital twin-driven product design, manufacturing and service with big data. Int. J. Adv. Manuf. Technol. 2017, 94, 3563-3576. [CrossRef]

184. Kedir, F.; Bucher, D.F.; Hall, D.M. A Proposed Material Passport Ontology to Enable Circularity for Industrialized Construction. In Proceedings of the 2021 European Conference on Computing in Construction, Rhodes, Greece, 25-27 July 2021.

185. Landahl, J.; Panarotto, M.; Johannesson, H.; Isaksson, O.; Lööf, J. Towards Adopting Digital Twins to Support Design Reuse during Platform Concept Development. In Proceedings of the NordDesign 2018, Linköping, Sweden, 14-17 August 2018.

186. Edge Olympic. Available online: https:/ / edge-olympic.com/ (accessed on 9 April 2021).

187. Longley, P.A.; Goodchild, M.F.; Maguire, D.J.; Rhind, D.W. Geographical information systems. In The Routledge Handbook of Mapping and Cartography; Alexander, K., Peter, V., Eds.; Routledge: New York, NY, USA, 2018.

188. Wuyts, W.; Sedlitzky, R.; Morita, M.; Tanikawa, H. Understanding and Managing Vacant Houses in Support of a Material Stock-Type Society-The Case of Kitakyushu, Japan. Sustainability 2020, 12, 5363. [CrossRef]

189. Kleemann, F.; Lederer, J.; Rechberger, H.; Fellner, J. GIS-based Analysis of Vienna's Material Stock in Buildings. J. Ind. Ecol. 2016, 21, 368-380. [CrossRef]

190. Verhagen, T.J.; Sauer, M.L.; van der Voet, E.; Sprecher, B. Matching Demolition and Construction Material Flows, an Urban Mining Case Study. Sustainability 2021, 13, 653. [CrossRef]

191. Munaro, M.R.; Fischer, A.C.; Azevedo, N.C.; Tavares, S.F. Proposal of a building material passport and its application feasibility tothe wood frame constructive system in Brazil. IOP Conf. Ser. Earth Environ. Sci. 2019, 225, 012018. [CrossRef]

192. Cai, G.; Waldmann, D. A material and component bank to facilitate material recycling and component reuse for a sustainable construction: Concept and preliminary study. Clean Technol. Environ. Policy 2019, 21, 2015-2032. [CrossRef]

193. Luscuere, L.M.; Zanatta, R.; Mulhall, D. Deliverable 7-Operational Materials Passports; BAMB: Brussels, Belgium, 2019.

194. Jayasinghe, L.B.; Waldmann, D. Development of a BIM-Based Web Tool as a Material and Component Bank for a Sustainable Construction Industry. Sustainability 2020, 12, 1766. [CrossRef]

195. Bertin, I.; Mesnil, R.; Jaeger, J.-M.; Feraille, A.; Le Roy, R. A BIM-Based Framework and Databank for Reusing Load-Bearing Structural Elements. Sustainability 2020, 12, 3147. [CrossRef] 
196. Li, S.; Xu, L.D.; Zhao, S. The internet of things: A survey. Inf. Syst. Front. 2014, 17, 243-259. [CrossRef]

197. Copeland, S.; Bilec, M. Buildings as material banks using RFID and building information modeling in a circular economy. Procedia CIRP 2020, 90, 143-147. [CrossRef]

198. Interact. Available online: https:/ / www.interact-lighting.com/global (accessed on 16 March 2021).

199. Company, M. Polder Roof. Available online: https://metropolder.com/en/\#polderroof (accessed on 16 March 2021).

200. MAPIQ. Deloitte, Amsterdam. Available online: https:/ /www.mapiq.com/customer-story/deloitte (accessed on 16 March 2021).

201. Lamptey, T.; Owusu-Manu, D.-G.; Acheampong, A.; Adesi, M.; Ghansah, F.A. A framework for the adoption of green business models in the Ghanaian construction industry. Smart Sustain. Built Environ. 2020. [CrossRef]

202. Ellen MacArthur Foundation. Intelligent Assets: Unlocking the Circular Economy Potential. 2016. Available online: https: / / www.ellenmacarthurfoundation.org/publications/intelligent-assets (accessed on 16 March 2021).

203. Ellen MacArthur Foundation. Towards a Circular Economy: Business Rationale for an Accelerated Transition. 2015. Available online: https: / www.ellenmacarthurfoundation.org/publications / towards-a-circular-economy-business-rationale-foran-accelerated-transition (accessed on 5 March 2021).

204. Bruce, C.; Sweet, K.; Ok, J. Closing the Loop-Recycling Waste Plastic. In Proceedings of the Anthropocene. Design in the Age of Humans-25th International Conference of the Association for Computer-Aided Architectural Design Research in Asia (CAADRIA), Bangkok, Thailand, 5-6 August 2020; pp. 135-144.

205. Marzouk, M.; Elmaraghy, A.; Voordijk, H. Lean Deconstruction Approach for Buildings Demolition Processes Using BIM. Lean Constr. J. 2019. Available online: https:/ / research.utwente.nl/en/publications/lean-deconstruction-approach-for-buildingsdemolition-processes-u (accessed on 16 March 2021).

206. Nazareth, A.P. How close is the built environment to achieving circularity? In Proceedings of the SBE19 Brussels BAMBCIRCPATH “Buildings as Material Banks-A Pathway For A Circular Future”, Brussels, Belgium, 5-7 February 2019.

207. Migliore, M.; Talamo, C.; Paganin, G. A Virtual Marketplace for Waste Valorization. In Strategies for Circular Economy and Cross-sectoral Exchanges for Sustainable Building Products; Migliore, M., Talamo, C., Paganin, G., Eds.; Springer: Cham, Switzerland, 2020; pp. 135-158. [CrossRef]

208. Chen, Z.; Huan, L. Digital Twin in Circular Economy-Remanufacturing in Construction. In Proceedings of the BEYOND 2020-World Sustainable Built Environment Online Conference, Göteborg, Sweden, 2-4 November 2020.

209. Gepts, B.; Meex, E.; Nuyts, E.; Knapen, E.; Verbeeck, G. Existing databases as means to explore the potential of the building stock as material bank. In Proceedings of the SBE19 Brussels BAMB-CIRCPATH “Buildings as Material Banks-A Pathway For A Circular Future", Brussels, Belgium, 5-7 February 2019.

210. Luscuere, L.M. Materials Passports: Optimising value recovery from materials. Proc. Inst. Civ. Eng. Waste Resour. Manag. 2017, 170, 25-28. [CrossRef]

211. Baiardi, L.; Ciaramella, A.; Bellintani, S. A Development and Management Model for "Smart" Temporary Residences. In Regeneration of the Built Environment from a Circular Economy Perspective; Della Torre, S., Cattaneo, S., Lenzi, C., Zanelli, A., Eds.; Springer: Cham, Switzerland, 2020; pp. 337-346. [CrossRef]

212. Mocerino, C. Intelligence of LED towards innovative nanotechnologies in the efficiency of building envelopes. In Proceedings of the International Conference in Engineering Applications (ICEA), Sao Miguel, Portugal, 8-11 July 2019; pp. 1-6.

213. Talamo, C.; Pinto, M.R.; Viola, S.; Atta, N. Smart cities and enabling technologies: Influences on urban Facility Management services. In Proceedings of the SBE19 Milan-Resilient Built Environment for Sustainable Mediterranean Countries, Milan, Italy, 4-5 September 2019. 